Florida International University FIU Digital Commons

$11-1-2012$

\title{
A Critique of the Representation of Violence in American Literature:
}

Tatiana E. Knight

Florida International University, tatik2000@hotmail.com

DOI: $10.25148 /$ etd.FI12113002

Follow this and additional works at: https://digitalcommons.fiu.edu/etd

\section{Recommended Citation}

Knight, Tatiana E., "A Critique of the Representation of Violence in American Literature:" (2012). FIU Electronic Theses and Dissertations. 751.

https://digitalcommons.fiu.edu/etd/751

This work is brought to you for free and open access by the University Graduate School at FIU Digital Commons. It has been accepted for inclusion in FIU Electronic Theses and Dissertations by an authorized administrator of FIU Digital Commons. For more information, please contact dcc@fiu.edu. 


\section{FLORIDA INTERNATIONAL UNIVERSITY}

Miami, Florida

\section{A CRITIQUE OF THE REPRESENTATION OF VIOLENCE IN AMERICAN \\ LITERATURE: THOMAS BERGER'S LITTLE BIG MAN}

A thesis submitted in partial fulfillment of the

requirements for the degree of

MASTER OF ARTS

in

ENGLISH

by

Tatiana E. Knight 
To: Dean Kenneth G. Furton

College of Arts and Sciences

This thesis, written by Tatiana E. Knight, and entitled A Critique of the Representation of Violence in American Literature: Thomas Berger's Little Big Man, having been approved in respect to style and intellectual content, is referred to you for judgment.

We have read this thesis and recommend that it be approved.

Yvette Piggush

Heather Russell

Bruce Harvey, Major Professor

Date of Defense: November 1, 2012

The thesis of Tatiana E. Knight is approved.

Dean Kenneth Furton
College of Arts and Sciences

Dean Lakshmi N. Reddi University Graduate School

Florida International University, 2012 


\section{DEDICATION}

This thesis is dedicated to my Mom, Dad and David for believing in me when I did not believe in myself. 


\title{
ABSTRACT OF THE THESIS \\ A CRITIQUE OF THE REPRESENTATION OF VIOLENCE IN AMERICAN LITERATURE: THOMAS BERGER'S LITTLE BIG MAN
}

\author{
by \\ Tatiana E. Knight \\ Florida International University, 2012 \\ Miami, Florida \\ Professor Bruce Harvey, Major Professor
}

The purpose of this thesis was to draw new insights on Thomas Berger's classic American novel, Little Big Man, and his representation of fictional violence that is a substantial aspect of any text on the Indian Wars and “Custer's Last Stand”. History's major world wars led to shifts in the political climate and a noted change in the way that violence was represented in the arts. Historical, fictional, and cinematic treatments of "Custer's Last Stand" and violence were each considered in relation to the text. Berger's version of the famed story is a revision of history that shows the protagonist as a dualmember of two violent societies. The thesis concluded that Berger's updated American legends and unique "white renegade" character led to a representation of violence that spoke to the current state of affairs in 1964 when the world was becoming much more hostile and chaotic place. 


\section{TABLE OF CONTENTS}

CHAPTER

PAGE

I. INTRODUCTION: Deficiencies in the Scholarship on Violence.................................

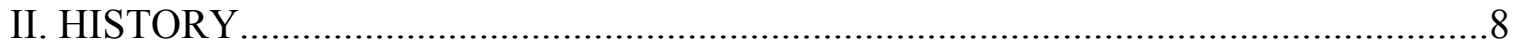

The Challenge of Authentically Representing Violence ............................................

Racial Conflict: Americans Conquer the Plains ........................................................... 12

George Armstrong Custer in Fact .......................................................................... 17

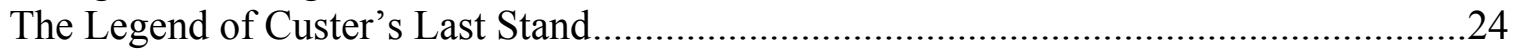

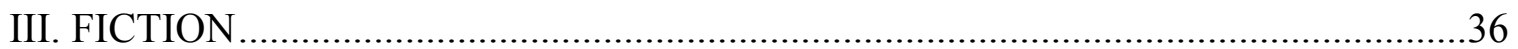

Printed Representations of Violence and White Renegades.........................................36

White Renegades in American Literature ................................................................39

Dissecting the Novel: Three Key Representations of Racial Conflict.............................57

IV. FILM

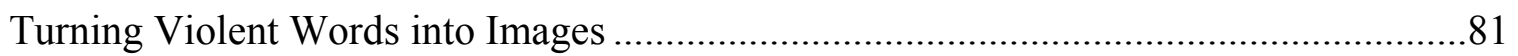

Subsequent Characterizations of George Custer in Film ........................................... 85

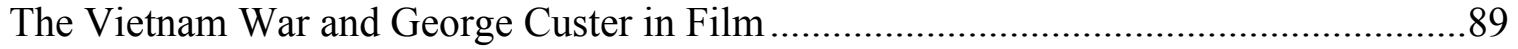

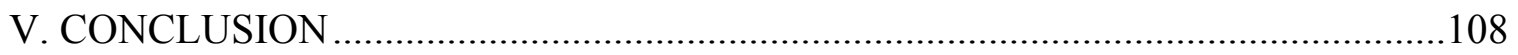

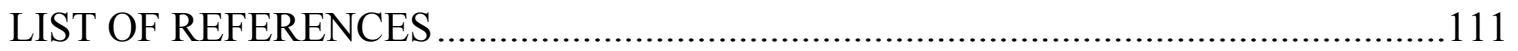




\section{INTRODUCTION: Deficiencies in the Scholarship on Violence}

In 5,000 years of recorded civilization mankind has written his history in blood.

Introduction, Soldier Blue

No one engaged in thought about history and politics can remain unaware of the enormous role violence has always played in human affairs, and it is at first glance rather surprising that violence has been singled out so seldom for special consideration.

Hannah Arendt, On Violence

Violence is a universal phenomenon within human society that is difficult to define and discuss, but is also a subject that deserves attention because it is very widespread and includes intense actions such as fighting and dying. The simplest explanation that can be given is that real violence is an act involving physical force intended to hurt, damage, or kill someone or something. As Michael Kowaleski points out in his study Deadly Musings: Violence and Verbal Form in American Fiction, "violence is a catch-all term, a kind of verbal wooden nickel, used with such frequent ease that its actual indeterminate status appears almost self-evidently clear" (10). The fact that the same word is used to describe such a wide variety of actions virtually leaves the expression devoid of meaning. For example, a door or a hammer can be violently slammed just as a person can be violently slapped or killed. Kowaleski goes on to define violence as "an act of aggression that is usually destructive, antisocial, and degrading in its consequence and that usually seems deliberate" (7). The majority of synonyms for the term, such as hostile, brutal, carnal, and ferocious aptly express the negative aspect of the term that is embedded in most definitions.

In her 1969 study entitled On Violence political theorist Hannah Arendt describes the 1900s as a century of violence. The philosopher views the phenomenon as a part of 
the timeless struggle for power. During the years that have followed Arendt's publication, there have been several new studies that have discussed human brutality in the most literal forms. The majority of the texts that were initially reviewed in preparation for the current study are concerned with riots, mass murders, and global warfare throughout history. Up until this point, violence has been described as an aggressive physical act, but the purpose of the current study is not to question why brutal acts are widespread in human society. Instead of looking at the phenomenon the way that a behavioral psychologist might do, the current study will focus on violence as it appears in literature, otherwise known as fictional violence. Fictional violence is a printed representation of real violence and the two are closely related, yet different.

Kowaleski explains that the only presence that violence has in fiction is verbal. In other words, violence in literature is created by a combination of words, which always appears as something that has been carefully designed by the author. Each artistic representation is unique because the creator includes his or her own ideas, beliefs, and biases in the final product. Studying the ways in which carnal emotion is exhibited to the public, in writing or on-screen, is important because the methods of presentation have a marked effect on the way that individuals view or understand the history of real or imagined violence in the United States. The history of "American violence" or what might be termed "violence of the victors" encompasses everything from the accounts of the birth of the nation when colonists fought for independence, the wars against the aboriginal inhabitants of the continental U.S. for land and the world-wide conflicts in modern times for global power and sovereignty. 
Research shows that whites and natives came into contact as early as the 1600 s1700 s, and had both peaceful and hostile relations. In the following century, when America had firmly established its independence from Great Britain, citizens had to fight for territory and resources against the Indians living on the land. The Indian Wars against the natives of Great Plains are some of the most violent struggles in the country's history books and these wars have left a lasting impact in America on both sides of the dispute. The Battle of Little Bighorn between Indians and the Army is one of the most famous clashes from that series of fights, both because of the amount of lives that were lost and because it was a significant turning point in American-Indian relations that ultimately led to the natives' final loss of their land. The details of the fight were first recorded in history books as military explanations of the battle. The tale was then highly fictionalized as "Custer's Last Stand" and joined the list as one of the best known American legends of all time. Custer historian Nathanial Philbrick theorizes about the event and its impact in the introduction to his study entitled The Last Stand: Custer, Sitting Bull, and the Battle of the Little Bighorn (2010):

Custer's transformation into an American myth had much to do with the timing of the disaster. When word of his defeat first reached the American public...the nation was in the midst of celebrating the centennial of its glorious birth....Much like the sinking of the unsinkable Titanic thirty-six years later, the devastating defeat of America's most famous Indian fighter just when the West seemed finally won caused an entire nation to wonder how this could have happened. We have been trying to figure it out ever since (xvii).

Thomas Berger's novel Little Big Man treats the Indian Wars in detail. The plot revisits the events in the West between the years of 1852 and 1876 and uses a mixture of historical facts and imagined stories to offer a new understanding of frontier life at this time. The main character is Jack Crabb, the 111-year-old former frontiersman, Indian scout, gunfighter, buffalo hunter and adopted Cheyenne. The story is allegedly written 
from a manuscript of Crabb's interviews with frontier historian and Indian enthusiast, Ralph Fielding Snell. Amongst the various escapades of his early years, Crabb resides with the Cheyenne under the leadership of Chief Old Lodge Skins and serves as a scout for the $7^{\text {th }}$ Calvary under the command of General George Custer. Throughout the course of the narrative, Crabb positions himself as an insider of two opposing realms and moves back and forth from one group to another. He also takes a restrained, yet active role in "frontier violence" on both sides. Most importantly, the protagonist vehemently claims to be the sole white survivor of Custer's Last Stand.

The novel was published in the middle of the 1960 s when there were the beginnings of new ways of understanding and treating violence in society and the arts, as well as growing debates about racism and citizens' rights in the U.S. In light of the changes taking place in the world around him, Berger's novel is steeped in violence and includes one bloody event after another. He offers an updated view of the American history that debunks established ideas about the "Old West" and also communicates a very positive message about the native way of life as the author imagines it. Berger adds a touch of humanity to Indian characters, as well as the world historical individual, General George A. Custer, who has been negatively treated by many artists since the 1930s.

The book is one of the best known fictional writings about Custer and is the author's most remembered work. It can easily be argued that one of the most noteworthy aspects of the novel is the fact that it contains numerous themes of what is understood to encompass "early American life". At least six chapters of the book read like a real captivity narrative and focus on the experiences of an adopted Indian during the time 
when the tribes were still generally free of white restrictions The last few episodes of the story that concern General Custer and the Battle of Little Bighorn make for a separate novel about Army life and waging war in the late 1800s. The chapters in the center of the story take the protagonist back to white civilization and serve as a story about the old West during the first one hundred years of the nation's existence. Each of Jack's different employments or adventures combine to paint a compelling portrait of what life was like for many men and women who were trying to survive and make a new life in alien territory that had only been their home for a few generations and was still full of strange beings. The fact that Little Big Man includes all of these themes and takes the audience into so many different worlds is what helps to make it such a widely regarded classic American novel that makes mention of anything and everything that may have gone on in the country at this particular point in history.

Berger's creation is celebrated by critics for its accuracy in depicting the culture of the Indians on the Great Plains as well as U.S. Army life of the period. The novel's value in this regard is a result of the author's extensive research of over seventy sources in preparation for writing. By 1964, a substantial amount of texts had focused on the Frontier, Indians, General Custer, and the Last Stand ad nauseam, yet Berger's novel readdresses all of these subjects with a postmodern approach and questions any and all earlier reports of the "facts" of American history. According to Frederick Turner's essay "The Second Decade of Little Big Man", the novel was initially more of an underground success within the academic community. Brooks Landon is the foremost Berger critic in the country and published the first book-length study on the author and his work. Landon finds that "while [the novel's] genius was not immediately apparent to large numbers of 
readers or to all initial reviewers, that genius has been at least implicitly acknowledged by some two dozen scholarly studies and by uninterrupted popular sales" (31). As Landon points out, a respectable amount of critical attention has been given to Little Big Man in the last forty-eight years. In 1994, author and educator Brian Dippie praised it as "the best novel about Custer's Last Stand yet written" (73). Although writers have had a lot to say about General Custer and Berger's novel, a review of scholarly works on the subject resulted in zero considerations of the representation of violence within the novel.

Many years have passed since the novel was first published, but the representation of human hostility within the story is a clear example of the ways in which violence affected the arts in 1964 when it was written. With the opportunity to explore a new avenue, the current study will consider the representation of violence in American Literature of the mid-to-late 1900s, as evidenced in the numerous treatments of the American Indian Wars and the Battle of Little Bighorn.

Chapter one will treat the difficulties of representing real violence and survey previous scholarship on the subject. The section will also work to situate Berger's novel within the canon of literature concerning the history of the Battle of Little Bighorn and the fiction of Custer's Last Stand.

Chapter two will treat the protagonist as a white renegade who is a member of a long-standing genre of American Literature that is closely associated with violent actions and explain the major differences between the typical renegade as opposed to Berger's unique renegade character and his position on human brutality. The section will also study the three most significant episodes of violence within the novel and disuses the 
artist's various methods of representation in an attempt to create new terms with which to discuss fictional violence and its symbolic significance.

Given that movies are the most popular arena for promoting legends in modern times, chapter three will study the representation of violence in American cinema. In the early 1970s, the Western movie genre staged a comeback with several films known as "Vietnam Westerns". The updated version of the original Western format employed the details from historical events that took place in early America during the Indian Wars to communicate a message about the events that were going on at the time that the films were produced, notably the Vietnam War overseas. The chapter will focus on Arthur Penn's Vietnam Western Little Big Man, as well as a selection of related films to illustrate the changing patterns of the representation of violence in the visual arts as sympathies changed and racism became more of a highly contested issue.

The expectation is that the current study will serve as the first evaluation of the ways in which each of the artists that are included use fictional violence to enhance their respective works and send certain messages to audiences. 


\section{HISTORY: The Challenge of Authentically Representing Violence}

Berger's protagonist is a white-renegade/adopted Cheyenne who describes the pain and suffering of armed military conflict between U.S. troops led by George A. Custer against the assemblage of "hostile" natives on the Great Plains. It should be noted that this is a fully loaded statement where there is a challenge of authentically representing or discussing virtually every term from the sentence. Each of the difficulties will be treated in sections that follow.

Firstly, there is no disputing that violence has been represented in American arts since the country was first founded. As David Brion Davis notes in his essay "Violence in American Literature", "For more than one hundred and sixty years American Literature has shown a peculiar fascination with homicidal violence" (29). He also notes that brutal events have been a part of literature since before the United States even existed and argues that there are number of significant works that do not include any violence at all. Famed literary critic, Leslie Fiedler, also recognizes that "American literature is distinguished by the number of dangerous and disturbing books in its canon- and American scholarship by its ability to conceal this fact" (11). The few studies that consider fictional hostilities often highlight America's widespread interest in the subject and attempt to answer the question as to why the general public seems to enjoy representations of human brutality as much as it does.

Davis argues that imagined or fictional violence is exciting for audiences and is included to captivate viewers with fleeting attention spans. Though Davis sees an overabundance of the representation of the phenomenon, he also cautions that the 
frequency of fighting and killing in American Literature is not necessarily proof of an unusually hostile society because literary treatments of violence have reflected certain historical conditions and circumstances (28). If Davis' theory is to be believed, one might go one step further to state that violence in the arts demonstrates less about the aggression level of its depicter and more about what is occurring in society at the time in which it is produced. Therefore, one can look at the ways in which violence in represented in a work to learn more about the ways in which violence was understood and treated at the time of the work's creation. To date there are no established guidelines for the artist or the critic to treat represented violence, but the general consensus is that it is a symbol for something deeper that lies within the text and that it is the critic's task to guess at that significance and uncover the message that the author is working to send.

A study of the representation of violence, especially one that covers armed military conflict, necessarily includes a discussion of the representation of pain. In The Body in Pain: the Making and Unmaking of the World, Elaine Scarry states, "Physical pain does not simply resist language but actively destroys it, bringing about an immediate reversion to a state anterior to language, to the sounds and cries a human being makes before language is learned" (4). Scarry argues that the very nature of pain virtually defies description because it often reduces one to yelling or crying in a primitive way such that the person in pain can never accurately describe their suffering because there are no words that fit. The writer also claims that humans need sensory confirmation of another's pain and suffering because they naturally doubt the existence of anything that is not clearly visible. 
Given that pain is not always evident to onlookers, Scarry states that the aspects of pain that are obvious, such as the weapon and the wound (both actual and imagined) may be used associatively to express pain (16). When speaking of the arts in general, Scarry states that "the person in pain might find it reassuring to learn that even the artistwhose lifework and everyday habit are to refine and extend the reflexes of speechordinarily falls silent before pain" (10). In other words, the difficulties of effectively communicating the idea of pain are compounded when the artist must take a real feeling and convert it to a verbal explanation that has the power to affect a response from the audience. The challenges of creating authentic fictional descriptions of real human sensations might explain why the representations of pain and violence in literature are sometimes absent, denied, or unsuccessful.

Arendt states that war is the most severe form of violence. Scarry defines war as a form of human brutality where the main activity is injuring and the ultimate goal is to out-injure the opponent (12). Despite what one may think, soldiers are not sent out into an enemy territory to defend themselves or their countries, but to demolish the competition by inflicting as much devastation and death as possible. As Scarry writes, "the act of mis-describing torture or war, though in some instances intentional and in others unintentional, is in either case partially made possible by the inherent difficulty of accurately describing any event whose central content is bodily pain or injury (63). The fact that pain is impossible to communicate only contributes to the reality that perpetrators often decide not to divulge the unpleasant details of their aggressive actions.

The Body in Pain lists several ways in which the representations of the acts of war conceal the fact that the objective is actually death by means of destructive deeds. 
Violence is diminished in both fictional and non-fictional accounts by means of creative explanations where syntax plays an important role in the way that the clash is represented. The first practice, known as Omission, is the deliberate exclusion of information so that an account appears less harsh. Scarry argues that military descriptions very often omit the fact that their main purpose is to injure or kill. The second tactic used to hide the brutality of war is known as Active Redescription. The term means that new words are substituted with others to portray the act of injuring, the tissue that is to be injured, or the weapon that causes the injury, in a more delicate way. In this vein, the fact that an Army plans to attack and kill the enemy can be re-described with words like "neutralizing" and "liquefying", which are both phrases that do not appear to involve the loss of human life. Often times, armed attacks are called "clean ups", which sounds like a positive step towards better organization or appearance and hides the deadly undertones that are associated. In some cases, the human being to be killed is actively redescribed as a weapon that must to be stopped, which shifts the focus from a dead person to a deactivated piece of equipment.

In addition to Omission and Active Redescription, the book lists four similar tactics that deal with word usage which are implemented to make the death and suffering seem more like the unfortunate or unforeseen outcome of war, rather than the desired outcome. The fact that war centers on inflicting pain means that the actions often defy description, both because they are too complex express and because they are often purposely veiled by those who sanction and carry out the bloodshed. The six methods detailed in The Body in Pain work to prove Scarry's theory about the challenges of talking or writing about real and imagined violence. In a world where human brutality 
cannot be accurately represented, it is no surprise that American Literature begins with the misrepresentation of the real and fictional Indians and their mysterious relationship with violence.

\section{$\underline{\text { Racial Conflict: Americans Conquer the Plains }}$}

Before fighting and war between whites and Indians could become a common element in American Literature, it first became a widespread reality of life on the Great Plains. At the time, aggressive or carnal actions were a basic part of survival on the frontier. A warrior had to track and kill living creatures for sustenance and other times in self-defense in the case of predatory animals. Braves also fought neighboring tribes on a regular basis. Men might have battled to protect their land, to gain new land, to acquire captives as slaves or wives, for honor, for revenge, or for entertainment.

Research shows that many of the aboriginal peoples on the Great Plains celebrated and ritualized violence. To commit a violent act against tribal enemies was the foremost way a boy could prove himself a man. Fighting was the central way to gain recognition and any warrior who put himself in the face of danger was respected for his courage, whether he survived or died. In the case of the Cheyenne Indians, a boy was officially recognized as a man after he did grown-up things such as fight in war and kill and enemy. Physical brutality was a part of an Indian's life from early on and research shows that the vast majority of the games that the boys played somehow involved violence and the threat of pain. Oglala Sioux, Black Elk, had his life story published in 1932 wherein he describes the ways that he and his boyhood friends would wrestle, play 
war, and practice tipping one another off of horses (16). Each of these games and others like them were created to train a young man for his future career as a warrior.

The natives living on what would later become U.S. soil did their best to withstand the invading Spanish, French, Mexicans, Texans and Americans over a period of almost three hundred years of white and native relations. When Indians and Americans first came into contact, interactions were generally peaceful and settlers were allowed to pass through native territory unmolested. The two groups traded goods and learned to communicate. The Indians utilized many of the settlers' goods, but only seemed to tolerate the incomers because they always expected that they would eventually leave. Once it became clear that the Americans were not planning to go away, the issues began to mount.

Some tribes responded to white encroachment by vowing to defend their sacred homelands or die trying. As author Stephen Ambrose states in Crazy Horse and Custer: the Parallel Lives of Two American Warriors, "None [of the natives] resisted more fiercely than the Sioux, the only Indian nation to defeat the United States in war and force it to sign a peace treaty favorable to the red man" (8). Any natives with an anti-American position like the Sioux were considered to be "hostiles" and violated government sanctions by continuing to roam freely on the plains. Young braves often exacerbated the issue by raiding settlements for supplies and killing settlers traveling on land that they considered to be Indian soil. The warriors quickly realized that aggressive attacks against Americans were far more profitable than their old ways of war against other tribes. Ambrose reasons that they were getting big American horses for themselves, and cattle, and all kinds of fine goods, such as new rifles, ammunition, canned food, blankets, and so 
forth (146). The natives' implementation of brute force allowed some tribes to successfully close off the trails used by white travelers and a few of the military forts on the furthest outreaches of the growing empire. When the American Civil War took place, the warriors experienced a significantly reduced opposition from the government and mistakenly thought that they had beat out the competition for control of the Great Plains. As soon as the war was settled there was a renewed presence of the American military on the frontier and a more focused effort to crush the Indian resistance, as they were the only outstanding enemies of the state.

In contrast, other factions opted for peaceful relations and chose to either avoid whites or to comply with the Government's demands for dominion over the Indians' highly coveted land and natural resources. White administrators signed numerous treaties with "friendly" tribes, but the terms were rarely upheld by either side. Firstly, Indians may not have known what they were agreeing to when they signed and/or might never have had any intention of abiding by the terms. Secondly, no single Indian had the power to speak for other individuals or tribes because the people were never officially united under one ruling authority. Thirdly, the treaties guaranteed that the U.S. would give basic living supplies, but corruption and theft in the Indian Agencies led to depleted or sub-par provisions and the Indians never got what they were promised. Finally, the U.S. Army had pledged to help protect native citizens and their land from American settlers, but only feigned any efforts to discourage incoming whites. The main issues noted above, as well as some others, meant that any treaties were null and void from the natives' perspective. A high percentage of Indians realized they would benefit from the promise of safety on the government reservations and surrendered their weapons and horses to 
become wards of the state. Life on the reservation was exceptionally difficult due to the Americans' failure to provide the things that were necessary for a healthy existence. Food was old and in poor supply, filth and disease were common, and alcoholism and prostitution of squaws ran rampant. Shockingly enough, many of the natives who chose to be "friendlies" and comply with government regulations were repaid with armed attacks from U.S. troops. The best known example of an American assault on an entire reservation occurred on November 29, 1864 in Sand Creek Colorado. Military commander Colonel John M. Chivington induced Chief Black Kettle and his band of peaceful Cheyenne to camp at Sand Creek near Fort Lyon. The chief led his people to the designated area and hung an American flag as a symbol of peaceable relations between his tribe and the government. On this day of American history, the volunteer militia of six hundred whites attacked the village and killed a large portion of the inhabitants, many of who were women and children. As Ambrose states,

Chivington had raised an infantry regiment of hundred-day volunteers in Denver...composed of all the riffraff on the frontier. Fortune seekers of every type, drunks, cardsharps, gun fighters, and all the Indian haters of Denver...their sole aim was to kill as many Indians as possible, as quickly and safely as it could be done, and then get back the warm comforts of the whorehouses and gambling dens of Denver (151).

The assault was vicious and unusually hostile. Many of the women were abused and raped as a form of entertainment for the men. Even young children were killed without mercy. In the aftermath, the soldiers were later denounced as murderers by Army officials and the event worked to further tarnish the government's reputation and negatively affect Indian-white relations.

Much like the natives who had always argued about the correct way to deal with the encroaching whites, the American Government did not have a strict policy that 
dictated how the alien inhabitants should be treated. As time passed, more and more Americans flooded onto Indian land and ferocious attacks from Indians steadily increased. The outbreaks on the frontier led to outrage in the U.S. and a mounting push towards total domination. Leading government officials tried everything from legally buying the rights for the land, to signing treaties that offered Army protection and material goods as bribes, to assembling reservations that would move the natives out of the way, to virtually exterminating the whole race by destroying their central food source and planning Army attacks on whole encampments. Soldiers occupied all of the Western forts where the columns regularly marched out after "hostile Indians", often killing any and all natives that they encountered. Researchers often point out the fact that both sides of the conflict regularly responded to an attack by killing the next person that they found from the opposite side. Actions like these meant that many innocent Indians and Americans were caught in the cross fire and ended up dead as a result of actions committed by someone else of the same race.

History books are filled with information on the countless violent altercations that took place in the events surrounding the Indian Wars. Each side dealt several blows and was subjected to a great amount of injuries and deaths. Events like the Sand Creek Massacre contributed to the Indian's lack of trust or respect for Americans. Eventually, many of the tribes who had originally moved to the reservations looking for a better existence opted to leave. In 1875, an enormous exodus of Indians left their designated lands and congregated in a massive camp on the open plains of Montana near the Rosebud River. Author Nathaniel Philbrick calculates that the outflow from reservations averaged "a stunning seven hundred Indians per day" (111). Ambrose notes that the 
group was the largest gathering of natives and the most united front they had presented to the U.S. government since 1840. The group was headed by respected Sioux leaders, such as Sitting Bull and Crazy Horse, who reportedly encouraged everyone to come out for one last fight against the whites. Native testimony of the people who left the reservations shows that the vast majority of these people fully expected an armed conflict against the Americans in response.

President, Ulysses S. Grant, had the biggest impact on the Indian Wars when he and his administration issued an order that all area natives should either relocate to their assigned reservations by January 31, 1876 or face the Army as enemies. Several historians, including Ambrose have noted that Grant's demand was unreasonable because the Indians were not able to travel during the winter because the people and the animals would either freeze or starve to death on the long march. Historical records also show that Indian runners did not leave the forts in time to get to the message to the tribes and bring them back peaceably before the deadline had passed which proves that the government never intended to wait for the "hostiles" to comply. The Army started readying the troops for the campaign soon after the order was issued. President Grant's unyielding position led to the escalation of the war that would eventually claim the life of America's most famous Indian Fighter of all time, George A. Custer.

\section{George Armstrong Custer in Fact}

George Armstrong Custer, nicknamed "Autie", is best remembered for the bloody events surrounding his death when he was in his late thirties. George was born in Ohio in 
1839. He attended the U.S. Military Academy at West Point, graduated in 1861 (one year early) and went directly into the Union Army during the Civil War. Though he was still very young, he rose to a leadership position as a Brevet Brigadier General, was praised for his success in battle, and soon became a national celebrity as the famed "Boy General". Custer's notoriety came a result of the combination of his talent and a good reputation as a distinguished cavalry soldier as well as and his own efforts of selfpromotion by publishing accounts of his exploits while serving in the Army.

After the Civil War, he was stationed in various parts of the states and wrote more articles about his military adventures. In 1866 Custer was assigned to command the $7^{\text {th }}$ cavalry on the Plains and was generally unsuccessful in locating and defeating the local Indians. In his partial autobiography My Life on the Plains, the General admits that the "hostiles" that they were tracking frequently spotted the troops and were able to disperse before the Army could catch them. In 1868, General Philip Sheridan, Commander of the Military Division of Missouri, ordered Custer to lead a winter campaign that would catch the natives when they were most vulnerable and least likely to escape. The Battle of Washita was Custer's first major clash with the Indians. It was also his most successful attack by American standards because he and his men easily took control of their enemies.

Once they reached the winter campsite, he and his men surrounded the Cheyenne from all four sides and launched a dawn attack. The village was completely demolished. Tepees were burned to the ground, eight-hundred ponies were executed, and at least one hundred residents (mostly women and children) were executed. One enlisted officer, Major Joel Elliot, and his troop were sent in a different direction to try to block any 
Indians from escaping. The soldiers met with unexpected opposition and tried to fight back, but were overpowered and killed by the fleeing Indians. The bodies were stripped and mutilated and were not discovered until much later when a different troop was sent to survey the area.

The mixed outcome of the Washita campaign had a significant affect on the General's reputation in two ways. Some officials praised him for leading a decisive battle against America's only remaining enemies. Others claimed that the targeted Cheyenne were "friendlies" who did not deserve to die and compared the attack to the events at Sand Creek. One of Custer's more outspoken officers, Captain Frederick Benteen, was dissatisfied with the results and publicly denounced the General for his failed leadership. Soon after the campaign was finished, Benteen sent an anonymous letter to a local newspaper. The letter claimed that Custer had sent Elliot and his men to their deaths, cared little for their safety, and put very little effort into finding the men when he went missing. Custer was offended by the letter and demanded to know who had written. When Benteen stepped forward, Custer offered to fight for his honor. The two never fought, but the event led to a feud between Custer and Benteen that would continue at the Battle of Little Bighorn and only end after to two were deceased.

In 1874, General Custer was assigned to lead the Yellowstone Expedition which helped to open the Black Hills for gold prospectors and started a mass influx of whites in the West. Many native accounts of the Indian Wars, fictional and non-fictional, cite Custer's participation in the Yellowstone expedition as the event that infuriated the Indians to the point that they would later claim their revenge at Little Bighorn. As soon as the news about the discovery of gold in the hills broke, the government made great strides 
to purchase the sacred land from the natives. All attempts to peaceably takeover the territory failed, largely because the Indians were arguing amongst themselves about the decision to sell and how much they would ask. Some Indians wanted to get whatever money they could from the transaction and reasoned that the Americans were going to take the land no matter what. Others said they would rather fight to the death than give up the sanctified land of their ancestors.

The General had a very controversial career where he got into trouble a number of times, most notably when he testified about government corruption and implicated a close associate of President Ulysses S. Grant. Although the stories of the issues between Grant and Custer are well catalogued in Custeriana, they do not relate directly to the topic of the current study. The most important point to note is that Custer fell out of favor with the President and high ranking officials and was punished by being taken out of active service just before the "final" campaign against the Indians was set to begin. Powerful allies intervened on Custer's behalf and requested that he be reinstated to lead the troops. His friends were successful and Grant allowed Custer to return to active duty. Once he was assigned to a new post, it seemed that Custer might have been working overtime to regain the fame and popularity that he once had. After Custer's death, the theory that he was glory-hunting and trying too hard to make a positive impression started to circulate as an explanation for his quick decisions that seemed rash to those who were looking back at the event after it occurred. Today, it is still a widely held opinion that George Custer had fallen to his lowest of lows in the mid-1870s and was desperately trying at all costs to climb back to the top. Some sources even claim that Custer was working to gain 
favor in the public's eyes so that he could return from the Indian campaign and run for President of the United States.

By February of 1876, the Indians' failure to sell the Black Hills or abide by President Grant's demand to re-locate to the reservations meant that the Army would continue preparing to attack any Indians in unceded territory. The Army planned a threepronged attack to encircle the Indian camp that was believed to be in the vicinity of the Rosebud River or Little Bighorn River. Major General John Gibbon was moving from Montana, while General George Crook was coming from Wyoming. Because of Custer's earlier missteps, Brigadier General Alfred Terry was in charge of the column that included Custer. Terry and Custer departed from North Dakota on May 17. Early on, the group was split into separate wings which gave the General the freedom to take full control of the march from then on. The separate wings were ordered to follow specific routes and planned to converge on the morning of June 26, 1876 for the attack.

Famous for pushing his men to march with the bare minimum of food and rest, Custer and the $7^{\text {th }}$ cavalry found the Indian camp one day early for the scheduled meeting. Once the soldiers arrived to the point where the Indian camp could be viewed through binoculars, the troops halted to rest. The men and their mounts were understandably tired, hungry, and dehydrated after a long and difficult march in the dead of night over hills, into ravines, and through immense clouds of prairie dust. During their approach to the Indian camp, Custer's men had several encounters with natives that led the General to believe that he had lost the vital element of surprise. As soon as Custer accepted this idea as a fact, he ordered the men to prepare for the attack without the other troops who were still en route. Custer had been ordered to wait until the other troops 
reach the area but other setbacks had delayed Terry and Gibbon's columns and the men would ultimately arrive one day later than they had originally planned.

Instead, the General reportedly planned to implement the same strategy from the Battle of Washita and divided his regiment into four parts. Five companies followed Custer on the right side of the river and three companies went on the left route with Captain Benteen. The pack train of mules carried extra ammunition and supplies and followed slowly behind with an armed escort. The last three companies were led by Major Marcus A. Reno who was the second in command on the campaign and had just joined Custer's troop. Reno was instructed to take the most direct route to the camp and charge as soon as the enemy appeared. Reno's charge was the official start of the Battle of Little Bighorn. The soldiers started to charge and were ordered to stop and fight on foot and form a skirmish line. The Major and his men quickly realized they had underestimated their opponents and were amazed at the massive size and strength of the enemy that met the attack. After a short while of disorganized firing, Reno ultimately called for a retreat to the nearby trees where he was reportedly the first man to run towards safety. Almost one-third of Major Reno's command was killed in the retreat.

Meanwhile, Captain Benteen and the pack train never found any Indians on their route and returned to reunite with the remnants of Reno's detachment. The men serving under both commanders were besieged on high ground and were under threat of total annihilation. Although soldiers reportedly heard firing on the other side of the battlefield and assumed Custer might need help, none of the men were willing to break through the enemy line to reach Custer. Benteen and Reno claimed that they thought they had been abandoned, much like he did with Elliot and his men at the Washita. Philbrick notes the 
irony in the situation where Benteen and Reno were probably cursing Custer for leaving them at the very same time that the General and all of his men were dying on the other side of the battlefield. The survivors rigorously defended their position until the Indians gave up and vacated the area two days later. Benteen and Reno later learned that they were saved because the majority of the Indian braves were on Custer's side of the battlefield dominating the whites. After hours of fighting and killing all of Custer's detachment, the Indians choose to collect their dead and move their camp rather than continue the carnage by killing Benteen and Reno's men. If the Indians would have continued to fight, every single one of the American soldiers who traveled towards the Indian village could have perished.

On Custer's side of the battlefield which is now a historic site with a memorial to the fallen Americans and Indians, the General and his men began a charge soon after Reno's men attacked and may have surprised the natives by coming from a different direction. The Indians who were initially fighting against Reno rushed to where Custer and his men were fighting and completely outnumbered and overpowered the whites by a huge margin. The main facts known about this portion of the Battle of Little Bighorn come from native testimony, as they were the only surviving witnesses. All two-hundred twenty five men under Custer's command who rode into battle against the natives were killed, stripped of personal possessions and mutilated before the day was done. Two days later, General Terry and General Gibbon arrived well after the fighting was done and the Indians had already vacated the area. Terry and Gibbon found the corpses of Custer and his men all over the battlefield being eaten by scavengers and decaying in the sun. Some of the bodies were dismembered or thrown into the nearby ravine where some parts were 
later recovered. The outcome of the attack was first reported to American citizens on July $7^{\text {th }}, 1876$ and the story has been a topic of interest ever since.

\section{The Legend of Custer's Last Stand}

The deaths of over two hundred highly decorated and trained soldiers from the famed $7^{\text {th }}$ Calvary horrified the entire country. The story's intense appeal and all of the unanswered questions and theories about what might have occurred led to Custer-themed scientific studies, stories, pictures, paintings, carvings, films, and television shows, all belonging to a category known as Custeriana. The first works of Custeriana were created in 1876 soon after the news was reported. In fact, the discussion is still relevant more than a century later because treatments continue to be produced in the modern era. Research shows that at least sixteen new scholarly works about George Custer were released in 2012 alone.

Each citizen's view of the General and his actions during the Battle of Little Bighorn has been significantly affected by the numerous treatments of his life and death that have been created over the years. Representations of Custer's Last Stand attempt to fill the gaps of what went wrong and speak to America's deep-rooted fascination with the event where everyone on one side died and where so few details are known. Although all of Custer's men perished, a large portion of Reno and Benteen's men and many of the participating Indians were able to share their experiences before they died. Some writers tried to take a very technical approach by focusing on the facts that could only be verified by eye-witness accounts. Nathaniel Philbrick uses testimonies from the Sioux and 
Cheyenne who were present, as well as the soldiers from Reno's charge in his historical study. Other Custer enthusiasts have taken the scientific approach and surveyed the battlefield in Montana and exhumed corpses to create an explanation of what possibly occurred that day. Lastly, some writers have attempted to use the clues from Custer's military career and his writings to speculate about his strategic decisions in 1876.

Because not one soldier who stood on Last Stand Hill lived to tell the tale, any story about General Custer's portion of the battle is necessarily fictional. With little to no hard facts to ground the account, artists have been free to let their imaginations take over. Historical treatments of Custer's Last Stand and the events that preceded and followed each include a portrait of George Custer as a man and as a soldier. The writers often discuss the General's earlier achievements and then point out several of the mistakes that were allegedly made at the attack. One popular theory within the works on the battle states that erred when he attacked an unknown adversary. He did not know how many warriors were there, if they were looking for peace or war, and what kinds of weapons they had at their disposal. He is also condemned for driving his men to the point of exhaustion on the opening march, separating his command into too many small fractions, and for failing to wait for reinforcements.

When the first articles of Custeriana were created, citizens regarded the General as an American idol or what one historian has called a dead-lion. Custer's published writings about his life served to memorialize the man as a courageous hero. His loved ones, such as his wife Mrs. Elizabeth Custer and his friend who would later become his official biographer, Frederick Whittaker, vehemently worked to continue the tradition after he was gone. In these accounts, the heads of government were corrupt or flawed and 
General Custer was the hero who sacrificed his life for the good of the country. Despite their efforts, by the 1930s Mrs. Custer had passed away and was no longer able to preserve her husband's positive image in the public arena. Political events like World War I had also taken place and caused the violence of global conflict to become a very real part of the country's new reality.

At this pivotal point in history, Americans turned their backs on previously established notions about the place of violence in reality and in artistic creations and began to question everything they had once believed. Citizens were increasingly cynical or disillusioned. The creative world responded by working to expose the falsities of previously accepted accounts in a new style known as debunking. The movement against established ideas inevitably meant that the former portrait of George Armstrong Custer as the famed Indian-fighter came under intense scrutiny. Starting in the nineteen-thirties and going forward, an altered description of history and its participants began to emerge and Custer's new likeness as an arrogant failure or merciless killer came to dominate popular opinion. The writers began tearing away the old beliefs and replacing the legend with the story of a man who was foolish and arrogant and selfishly led hundreds of men to their deaths as a result of his numerous flaws. The majority of the works that were published at that time include a negative portrait of George Custer that marred the man's name and reputation in varying degrees.

The nineteen sixties was the next decade to see a lasting change in society and the arts. As Alexander Bloom explains in Long Time Gone: Sixties American Then and Now, "The sixties maintains a unique place in our continued life unlike that of any previous era...we are still debating issues that emerged in that decade, still living in the 
conscious aftermath of its events and transformations" (78). At this time in history, the youth clamored to have their voices heard and marginalized citizens such as African Americans, women, and gays, all established respective movements for equal rights. Monumental events which include the assassination of both John F. Kennedy and Martin Luther King Jr. as well as the start of the Vietnam War significantly changed citizens' attitudes towards the violence that had recently overwhelmed every aspect of American life.

The Vietnam War took place from 1961 to 1975 and resulted in roughly fiftyeight thousand American deaths and two million Vietnamese deaths. The war was not a highly contested issue at the start of the sixties because the government regularly reported encouraging, yet inaccurate news in an attempt to cover up the facts of the worsening campaign. Although the Americans had originally set out to "save Vietnam", the growing evidence was starting to prove otherwise. The campaign was the only time out of the eight foreign wars where the U.S. was defeated (Bloom, 49). Research shows that the general public credits ignorance or lack of information about the opponent, racism that under-estimated the opponents' abilities, and a stubbornness to admit defeat, as the Americans' foremost errors in Vietnam. It is important to point out that the theories that explain the loss at Vietnam are the exact same ones that were used a century earlier to describe Custer's mistakes at the Battle of Little Bighorn.

The Mai Lai Massacre in 1968 was the worst example of just how far the government was willing to go. On March 16, U.S. soldiers killed a substantial number of women, children and elderly in Mai Lai Vietnam. The invaders were responsible for mutilating, raping and killing an estimated four to five hundred Vietnamese non- 
combatants in one single day. They also burned the homes, killed the livestock, and destroyed food and water supplies, much like Custer and his men had done at the Battle of Washita. Once the attack was done, the U.S. Government labored to cover up the scandal for over a year. By the end of 1969 the facts were exposed and photos of the desecrated bodies were published in Time Magazine for everyone to see. Mai Lai and other stories from the Vietnam War shocked and outraged American civilians. Bloom explains that the war reports "forced the country to accept our own criminal behavior for the first time in a long time or ever" (61).

Once the government was exposed for lying about the nature of its intervention in the East, the backlash forced the anti-violence debate into the public eye and opposition to the war intensified. A widespread distrust of the government and its agents of foreign policy abounded and protest rallies gained more and more supporters. The highly publicized missteps by the administration during the nineteen-sixties and early seventies had a lasting effect on American society that soon trickled down into the creative arts. The country's writers, filmmakers, and musicians often utilized their influential positions by incorporating political messages into their work. As a result of the notable events that were occurring in the period, American artists were exceedingly cynical and set out to express ideas in a new and relevant way that would reach audiences. For a number of years, there were cultural taboos and censorship laws which blocked an excessive amount of violence from being openly portrayed or accepted in the arts, but those norms were necessarily amended as violence crept into American newspapers, television broadcasts, and everyday conversation after the truth about the war was exposed. 
As John Fraser notes in Violence in the Arts, the era saw an "intensification of the violence in violent works [and] a change in the attitudes of intellectuals towards them" (2). Cultural Historian, Paul Hutton, ties all of the relevant subjects together when he notes that:

The 1960s gave no respite to the tarnishing of Custer's legend. If the 1950s had seen a budding racial conscience in America, it came to full bloom amid the tumult of the 1960s. The plight of oppressed minorities became the concern of many Americans, and there was no longer room in the pantheon of heroes for those who had engaged in repression. Young people especially began to wonder if the values and heroes of American society were worthwhile and relevant. To an ecology-minded generation the winning of the West became synonymous with environmental exploitation and destruction. The settlement of the frontier was no longer a glorious affair but a murderous conquest accomplished over the dead bodies of innocent Mexicans and Indians. To many, Indian life offered a valid counterculture, a more organic, rational, and natural existence than that of white society. The Vietnam conflict, with its array of political and military blunders, gave rise to a bitter disdain of the military in particular and arrogant leadership in general. By the late 1960s comparisons of the Vietnam War and the Indian wars were becoming commonplace, and Custer, thought his image had changed, was still a symbol of those earlier conflicts (39).

The shift from viewing the American soldiers as heroes to seeing them as criminals who killed native inhabitants had a profound effect on the country's memory of the events of the Battle of Little Bighorn and its major players.

Nathaniel Philbrick's book The Last Stand: Custer, Sitting Bull, and the Battle of the Little Bighorn (2010) is one of newest studies on the subject. The work covers General Custer's final campaign against the Indians and is the end result of four years of research and a number of trips to the battle field. Although there is already a huge amount of scholarship on the subject, the book has received at least forty glowing reviews from critics who appreciate it as a significant contribution to Custeriana. In a review of Philbrick's book for Library Journal, critic Mike Rogers highlights the best aspect of the book as he points out,

Neither the golden-haired general nor the Indian chief here is the bloodthirsty warmonger often portrayed in other accounts. Both are top soldiers and natural leaders zealously looking out for their respective peoples' interests.....more than a detailed chronology of events...this book is an 
in-depth portrait of the two combatants.... Both shared tragic and triumphant lives indelibly woven into the fabric of American lore. (93).

Philbrick writes from a point of view that considers George Custer and Sitting Bull for their own strengths and weaknesses. The book is an important addition to the genre because it demystifies both famous leaders to treat them as real human beings. As the author explains in an interview about the book, at one time or another both Custer and Sitting Bull were heroes but both were also real and vulnerable people for whom the Last Stand was as much a tragedy as a vehicle to eternal fame.

Philbrick's stance allows him to offer a deeper understanding of what might have occurred in history as seen through the eyes of those that lived it. The Last Stand fluidly combines numerous sources by omitting all endnotes. He also takes liberties by weaving time and space together. For example, time is altered at the precipice of Custer's Last Stand and readers go back to ten years earlier to the Battle of Washita where Philbrick draws conclusions about the similarities between both offensive strategies. He also tells the entire story of what happens to troops commanded by Major Reno and Captain Benteen throughout a period of two days before going back to learn about the Last Stand to add an element of suspense. The account then moves from the General's death straight to Chief Sitting Bull's death to draw symbolic connections between the declines of both leaders, even though the events are chronologically fourteen years apart.

Philbrick merges various testimonies as a basis for his theories of what most probably happened in June of 1876. Although he considers various accounts from Americans who were at the Battle of Little Bighorn, a central aspect of the study is the fact that he emphasizes the experiences of the Indians who either lived through the attack 
or were related to someone who did. In fact, chapter fifteen about Custer's Last Stand is unique because it relies on native's recollections to tell the story. He shares a lot of what the Indians found to be noteworthy, like who counted coup and who was very brave. Chief Sitting Bull's commentary about what he thought when he first saw the soldiers attacking prompts readers to consider the event from the Indian perspective, which makes the book very sympathetic to the natives' experiences. The leader confesses that he and his men had initially approached Reno's battalion hoping to make peace and said that they were forced to retaliate without even knowing why they had been sought out by the military in the first place.

The facts of what took place at in certain portions of the battle are a main part of Philbrick's depiction of the event. The preface sets the tone for the book by stating, "Custer and his men were last seen by their comrades galloping across a ridge before they disappeared into the seductive green hills. Not until two days later did the surviving members of the regiment find them: more than two hundred dead bodies, many of them hacked to pieces and bristling with arrows, putrefying in the summer sun" (xxii). As these few lines illustrate, the account of the attack is a necessarily intense story and Philbrick will spare little detail when he depicts the physical violence. Despite the natives' history of war as something of a sport or hobby, the author is careful to justify Sitting Bull's response by saying that they had a reason to be outraged by the unexpected and aggressive intrusion.

When Philbrick refers to native testimony from the battle, he retells the Indian's version of what happened and does not pass judgment on the warriors for their actions. In the first instance, a twelve year old Lakota named Black Elk (who would later go on to be 
one of the most famous Indian thinkers and spiritual leaders of all time) is riding near the river when he comes upon a wounded soldier. An elder instructs Black Elk to scalp the soldier. As the Oglala Sioux admits in the original account that Philbrick quotes from, "I got off and started to do it. He had short hair and my knife was not very sharp, he ground his teeth, then I shot him in the forehead and got his scalp" (112). Though scalping someone alive is unthinkable for the vast majority of modern day readers, neither the brave nor Philbrick make excuses or apologies.

In another example of anti-white brutality, White Bull tells the story of his experiences:

White Bull plunged into the resultant pandemonium with a will...Ahead was a soldier with his carbine raised...When White Bull charged at him, the trooper threw aside his weapon and wrestled White Bull to the ground. The Lakota warrior soon found himself in the midst of a death struggle. The soldier tried to rip the rifle out of his hand, and when that didn't work, punched White Bull in the face and shoulders, then grabbing him by his braids, pulled his face toward him, and attempted to bite off his nose. White Bull cried out to the other warriors...In desperation, he screamed into the trooper's face at the top of his lungs. When the trooper's grip relaxed, White Bull pulled out his revolver and finally managed to pistol whip the soldier to death. "It was a glorious battle," he recalled. "I enjoyed it" (271).

Philbrick is sure to add the graphic details of the fighting, pain and suffering, death, and mutilation to give a very realistic account of what occurred at the Battle of Little Bighorn as the witnessing Indians testified. Both of the excerpts from native witnesses that are listed above are important to the text because they explain how the village was taken by surprise and upset to see that they had been attacked and that their friends and family were in danger. Therefore, revenge and justifiable violence are both themes that are included in Philbrick's text as possible explanations for the ferocity with which the Indians fought and killed at the site of the Little Bighorn. 
The Last Stand takes a straight forward approach to human brutality as a necessary part of war and there is little emotion in the story. Chapter ten entitled "Reno's Charge" includes various explanations of how the soldiers went to their deaths and each one is gorier than the next. Likewise, the chapters detailing Captain Benteen's defense of the hill contain the unpleasant recollections from the men who were fortunate enough to survive. According to Philbrick, Major Reno's charge resulted in forty deaths out of the one-hundred thirty men who fought. The Last Stand includes the details for about half of these fatalities. For most, the historian simply states that a soldier has been shot, hit, picked off, gone down and the reader is left to assume that they are dead. Other soldiers are described as being beaten with stone clubs and hammers, stabbed with arrows, and shot down. In several instances more graphic details are incorporated, such as the time where an Indian scout is shot and his blood and brains are spattered all over his friend's face.

In addition to the ways that many of the men die, the author also includes the details of how the bodies are mutilated post-mortem. The women and children are said to take a leading role in the abuse by using knives and other sharp tools to exact their revenge. To cite a few examples, the Indians scalp, decapitate, burn corpses, as well as cut off limbs and remove vital organs. All of the dead soldiers are also looted when Indians strip them of any clothing, jewelry or weaponry. The description of the battlefield after the fight explains that the bodies are so badly maimed that the soldiers have a difficult task to correctly identify each body. One of the most often cited examples are the remains of George Custer's younger brother and fellow soldier, Tom Custer, whose skull 
was pounded so thin that his face was literally unrecognizable. In this case, the unique tattoo on his arm was the only thing that helped the Army to identify the distorted corpse.

Philbrick's treatment of Custer's Last Stand makes a few key points about the event without adding too many details that cannot be verified by the survivor's accounts. His main contentions are that the Indians were working to protect their families and that Custer most certainly expected Captain Benteen to arrive with reinforcements that never came. The chapter includes a few explanations of how some of the men die, but overall it is the least detailed segment of the book. Philbrick uses metaphors that compare the Indian's charge on the hills to moving bodies of water and their slow advance to the slithering of snakes, in the exact same way that Berger does in his novel. Though at first it might seem that Philbrick has taken a cue from the novelist to re-create the unknown facts of the fight, a second look at the text reveals that the quotes that employ the figurative language that speak of the ocean, snakes, etc. are all taken from the actual native testimony from battle participants or witnesses and was not an original creation.

Because there are no facts to prove that it is true, Philbrick does not represent General Custer as the lone man standing at the end of the fight the way that most of the Custer legends do. Instead, he theorizes that the leader was at the safest part of the battle field and was probably one of the last to die, but also says that Tom Custer's body was so badly maimed that he might have been the fiercest fighter and last to die because natives were known to significantly abuse the best shot or best fighter from the opposing side. The "factual" account of the battle in The Last Stand is much less glorious than those from fiction and says nothing about the courage or legend of General Custer, famed Indian Fighter. All of the unanswered questions and gaping holes in the story are left 
open for readers to fill in the details with whatever they believe occurred, which is exactly what Berger does in his fictional version of the fight in Little Big Man and the other central occurrences of imagined violence in the novel. 


\section{FICTION: Printed Representations of Violence and White Renegades}

Berger's work is situated in the Custeriana category as well as being a member of the "renegade texts" of American literary history. The fifteenth century marked the start of a significant point in history when European settlers arrived in North America and encountered native inhabitants who had been living there for generations. As Colin G. Calloway notes in his essay "Neither White nor Red: White Renegades on the American Indian Frontier", the European invasion initiated a clash of cultures that was reenacted on successive frontiers as Indians and whites struggled for land and survival, and this cultural interaction produced various groups of marginal people who were condemned by fate to live in two different societies and in two, not merely different but antagonistic cultures (43). Some of these ill-fated individuals were known as traders, captives, Squaw men, mixed bloods, and renegades. Thomas Berger's main character takes on each of these marginalized roles within the novel, with the exception of the mixed bloods because he is born to white parents.

Calloway notes that the term renegade lacked precision in early America because there was a considerable amount of people who were unofficially classified as renegades and because white attitudes and suspicions ultimately determined who was or was not a traitor. All of the following individuals were classified as renegades at one point: white men living with native women in Indian country, captives who chose to remain in Indian villages, people of mixed parentage who lived with their Indian relatives, agents of foreign powers operating amongst aggressive tribes, outlaws and desperadoes, and even full breed Indians who continued to run free after their people had been confined to 
reservations. The failure to distinguish between the diverse types of frontier dwellers meant that often times any man who was married to an Indian was known as a Squaw man and accused of renegadism, as well as any of the children that came from the union of a white to a native, regardless of their respective guilt or innocence.

In her essay, "The Tribe Called Wannabee: Playing Indian in America and Europe" Rayna Green finds that the first known form of "playing Indian" was performed by European colonists who came to the Americas and utilized native survival tactics. The first Anglos left their countries of origin but did not intend to betray white civilization. The newcomers were searching for a way to stay alive in the world that was harsh and unfamiliar and may have simply taken cues from the local Indians. Though outward appearances suggest that white renegades were converted into real Indians, Calloway argues that most renegades were "independent intermediaries operating between two cultures rather than fanatical converts or defectors" who appear to have been driven to choose sides as the hostilities sharpened (65). Because they had rejected the race that they were born it to, renegades were often unpopular and uncomfortable in both the white and the native worlds. "Neither White Nor Red" represents the renegade as less of a superhero who can successfully cross from one society to another and more of a real person who is just doing their best to survive on the frontier. As Calloway explains:

Renegades left behind a legacy of fear and a reputation for evil that ensured them a lasting place in the folk history and mythology of the American frontier. They occupied a precarious intercultural position that earned them little but hatred and distrust. More than any other group, they appear to have threatened Euro-American assumptions of racial superiority, which in part explains the hostility with which contemporary writers attacked them...Ostracized for escaping from "civilization", they sought a home of refuge in or near to Indian communities. But very few found real homes or permanent refuge. Some could never forget that they were white; others found difficulty in accommodating to Indian society. Some attracted the suspicions of Indians as well as whites on the grounds that a man who turned traitor was apt to do so again (65-66). 
When referenced in any writings about the Americas, a renegade is a person who has turned against white Euro-Americans and sided with the indigenous inhabitants during a time period when both groups were consistently clashing. Roy Harvey Pearce defines a renegade as someone who has willfully given himself over to savagism (224). Calloway's research also shows that renegades had a reputation of being connected to cruel behavior and homicidal tendencies. In the eyes of the everyday American, a renegade was deranged, looking to escape his or her responsibilities in civilization, and might have committed atrocities before leaving to join the "savage" world where it was believed that anything and everything was allowed. Those who were able to survive the dangerous life of a renegade often tried to rejoin white society. Readjusting to different ways of living was a difficult process and few successfully returned. The white renegade's connection to his Indian friends meant that he and the natives would necessarily perish in a world that was quickly turning against them both. As Calloway notes,

Created and destroyed by the tide of westward expansion, all [renegades] were doomed to be overtaken by the unrelenting advance of the frontier and became trapped in a rapidly diminishing no-man's-land. Some died in the ensuing conflicts. Other accompanied the Indians on to reservations and lived out their days as "squaw men". A few successfully readjusted to life in the white man's world but remained objects of curiosity. Neither Indian nor white, renegades were forced to choose sides in the vicious racial wars of the American frontier. Having become identified with the Indians, they shared in the defeat and destruction of societies to which they never fully belonged and were vilified by the society from which they never completely escaped (66).

A good deal of information about historical renegades in early America is available and the historian cites several individuals who either wrote their own stories or had them recorded and published. On a frontier where natives consistently had to fight to stay alive, the white captives were forced to adapt to the new reality and frequently participated in armed conflict. Renegades usually learned how to hunt and fight with 
native weaponry and utilized the new skills to help their tribe prevail over outside threats. Calloway discusses the young boys and girls who were taken captive, stating that often, "home became the Indian village where they had spent most of their lives and to which they had become tied by marriage and children" and "they might have come to regard the enemies of their Indian friends and families and their enemies" (51). Research shows that some historical renegades strayed even further from their roots and decided to fight against other whites.

\section{$\underline{\text { White Renegades in American Literature }}$}

As renegades became well known figures in American life, they necessarily earned a place in its literature. A. Irving Hallowell finds that "despite the radical changes in intellectual climate from the eighteenth century, when the colonists were confronted with the disturbing realities of capture and many accounts of captivity were published, up until the present day---Indian captivity, the renegade, and Indianization have ever lost their fascination in the American public"(521). Renegade texts first arose when white captives recorded their real-life experiences as half-whites, half-Indians. After the 1860s, the white renegade emerged as a stock character in numerous fictional works of literature, most notably in the popular adventure stories known as dime novels. Colin G. Calloway's discussion of the renegade character in literature includes his theory on the common subcategories of renegade texts that include such majors themes as: the white warrior's story, the captivity narrative, the return to nature account, and those portraying the dilemma of the returning renegade (44). 
The Light in the Forest is just one entry in the vast catalog of renegade texts. The book was published by Conrad Richter in 1953 which is seven years after Berger's renegade text appeared. Richter's work is relatively short and the story does not have many levels of depth in terms of the psychological aspect of "going native" but is still important because it portrays Indian and white society from the inside out. The book focuses on Calloway's sub-genre known as the dilemma of returning to civilization. The main character is a white boy named John Cameron Butler who is captured at the age of four by the Lenape and lives with the Indians for eleven years. The story begins when the local soldiers demand that all white captives be returned to their rightful families. Cuyloga, True Son's Indian father, reluctantly returns the boy out of fear of the Americans.

The boy is called True Son by his adopted parents in an attempt to solidify his membership in the family and the tribal unit and grows up believing he is an Indian. The author indicates the character's identity as that of a native by always calling the protagonist by his Indian name. True Son is adamantly opposed to leaving the life that he has enjoyed for over a decade and is disgusted with white civilization from the moment that he reaches the home of his blood relatives. The boy soon decides to either poison himself or to find a time when he can escape. The renegade character is so closely associated with the Indian beliefs about aggressive action that he does not hesitate to use brute force for his own means. At the start of the novel he considers attacking the white soldier who is guarding him and he stands idly by as his white uncle is killed and halfway scalped during the escape. 
Once he is able to run away and return to his Indian family, he finds that his sympathies have changed and that he can no longer partake in any anti-white violence with his adopted family. The other warriors are disgusted with him and even consider burning him at the stake. Cuyloga stands up for his adopted son and manages to save the boy's life. Cuyloga tries to wipe away the transgression by disowning the boy and casting him out of the Lenape society with the threat that he will be killed if he ever tries to return. The novel's final message is that human beings cannot change or escape their true identities. As Cuyloga explains in their final conversation: "I look in your heart. I look into your head. I look into your blood. But your blood is still thin like the whites, it does not mix with the brave redness of Indian blood" (176).

Richter's ending demonstrates the idea that renegades do not belong in white society or Indian society and will be left in a virtual no man's land as punishment for failing to live by either culture's true standards. The Light in the Forest shows the effects of long-term captivity, as well as the difficulties of returning to white society after years of being away. Richter uses the work to make social commentary about the corrupt, immoral, or racist aspects of white civilization as seen by an outsider and offers the theory that crossing cultures leads to confusion where the main character no longer has a real grasp of who he is and what he stands for.

Fictional white renegades joined the Custeriana canon soon after the Battle of Little Bighorn occurred, as a direct result of Major Marcus Reno's post-battle report to the Secretary of War that stated that he and his men had failed to successfully charge the Indian encampment because they were up against all the desperadoes, renegades, halfbreeds, and squaw-men in the country. Contrary to Reno's assertions, Custer historians 
cite the recorded interviews of the natives who fought in 1876 who consistently deny that any renegade whites fought on their side. Whether or not he lied or was mal-informed, the testimony created a new legend about the battle and the connection between white renegades and Custer's Last Stand persists. Famed Custer expert Brian Dippie states that a favorite plot of the Last Stand literature places a renegade in the Indian camp during the fight. Dippie explains that the renegade sometimes survives the fight as a member of Major Reno's detachment and in other cases he "has a change of heart in time to go into the fray with Custer" (479).

One well-known renegade text from Custeriana that fits into both common clichés is Will Henry's No Survivors (1950). The main character is Colonel John B. Clayton whose diary is discovered and published after his death. Clayton is an American who is promoted to the rank of Colonel in the Confederate Army at the age of nineteen. Far from being a picaresque character that is purposely distanced from the actions in the story, Clayton is intimately involved with all of the events that occur in his life story and often plays an important part by affecting recorded history. He first comes into contact with General Custer when the South surrenders to the North at Appomattox. The protagonist goes so far as to represent himself as somewhat of a hero for stopping a trooper before he is able to shoot Custer down.

No Survivors is a renegade text related to Custeriana where the protagonist is extremely aggressive. The majority of John's life story is what might be called the ultra violent version of Berger's novel. One could easily argue that Henry's work is much more gruesome than Berger's because the protagonist willingly fights and kills numerous characters and has no remorse. The novel is the most detailed of all reviewed modern 
sources when it comes to the descriptions of battles, deaths and mutilations. After the conclusion of the Civil War, the character shows readers that he is no stranger to brutality when he shoots a man down at poker game and steals all of his money. This is just one of the many times that Clayton murders an opponent. John's introduction to the sometimes hostile Indians on the frontier comes when he is hired to escort an American wagon train through Montana where the Sioux are claiming dominance. Always trying to play the hero, Clayton learns on more than one occasion that the Indians are ready to attack the soldiers at the nearby Fort and rushes to warn the troops. In both cases the Army does not listen to his advice and the results are bad for the American side.

John is later selected to be the Army's civil scout and post hunter which leads him to participate in the historic Fetterman Massacre. The actual event occurred near Fort Phil Kearny in modern day Wyoming. According to Ambrose, the camp of Indians headed by the Sioux coordinated several attacks on the wagons that went from the Fort to the nearby pine woods to chop down trees and failed. On the day of what is now known as "The Fetterman Massacre", Captain William Fetterman was the principal tactical officer of the troop and was ordered to protect the wood train. Fetterman blatantly ignored his orders and followed what appeared to be a group of only ten Indians for a fight. Once he and eighty of his soldiers had traveled five miles away from the Fort, over two-thousand Indians that had been hiding in the hills emerged and attacked. Every one of the soldiers was killed. According to one of the accounts, Fetterman and another one of the Captains executed each other simultaneously with a pistol shot to the other's head. The bodies were abused and robbed of personal possessions. Ambrose claims that this battle was the 
first time that Indians had gained a decisive victory for their side, as well as the first time that they had a large amount of enemy bodies to abuse and torture for sport.

In the novel, the Colonel is able to survive the attack even when all of the enlisted soldiers perish. The protagonist is badly wounded and overtaken by the Sioux, but is spared by Crazy Horse, head warrior, for his impressive courage in battle. John Clayton then becomes an adopted member of the Oglala Sioux for the next decade and learns how to be an Indian warrior. During a Sioux ritual, pledges to leave his white identity behind and takes on the new name Cetan Mani (Walking Hawk) because of his speed and fierceness in the chase. Henry's characterization of Indians is generally very positive and John respects Crazy Horse for his balanced combination of ferocity, fearlessness, kindness, and gentleness.

One of the most important points in the novel occurs at the Battle of the Rosebud when John is repulsed by the sadistic side of Indian versus white violence. As the protagonist admits, "when the mutilation began my Indian blood thinned rapidly, for the first time in fifteen years of fighting I had no answer to the questions which pound at every man's mind when the battle grows desperate: "Why am I here? Who am I serving? For what am I about to die?" (212). Clayton's remorse and sudden change of heart is noteworthy because it shows that he is modeled after a real human being who makes mistakes and must stop to question himself and right the wrongs. John subsequently decides to return to the Army camp and lobbies for Custer to cancel the attack at the Little Bighorn. The General refuses to listen and the former Colonel elects to ride with the regiment. The author first describes the start of the battle when Reno and his men charge and retreat. Clayton survives the initial skirmish and is able to make it to the other 
part of the battlefield before Custer and his men are all killed. The ending is a combination of the two scenarios that Dippie most commonly finds in Custeriana. In this particular representation of Custer's Last Stand, the General is cursed for his pride and arrogance that takes him and his men into a death trap, but he is also celebrated for his courage and conviction under duress.

The final message of Will Henry's novel is that General Custer died as a result of his own failures in leadership and the white American greed and racism that pushed the government leaders towards theft of land and extermination of the Indian other. As usual, the natives are represented as benevolent characters that are illegitimately abused by the United States. The story ends with the real death of Crazy Horse and the symbolic death of Plains Natives, as many of the novels of the genre do. Most importantly, the renegade in this text is resigned to a lonely and unhappy fate as he is outcast from both societies, treated as a ghost because both sides hear about his supposed death, and left to ultimately die alone. Just as Calloway's explanation of the crushing tide of Americans on the Plains states, all natives and the white men who associated with them will end up dead because they have no home in the new society that ostracizes and exterminates outsiders.

The renegades in The Light in the Forest and No Survivors both have a loss of identity as a result of their experiences with one foot in each world. Author Thomas Berger also uses this theme is his work Little Big Man. In this novel, the elderly Jack Crabb shares his life story from the comfort of his nursing home. According to the account, he lives as a white renegade who positions himself as an insider of two opposing realms and moves back and forth from the Indian camp to white civilization multiple times in his life. Compared to John Clayton, Jack takes a restrained role in the hostilities 
associated with life on the frontier. Berger's novel is written in a way that makes the story a captivity narrative, a white warrior's story, and a story of returning to white civilization, all at once. The point is worth noting because the characterization offers both the positive and negative aspects of Plains Indians lifestyle. Though the novel uses traditional forms of renegade literature described in the Calloway essay to tell Jack Crabb's story, the character's aversion to human brutality makes him stand out from other renegade characters in American literature. Throughout the majority of the account, Jack explains that he does not enjoy the fighting and killing and often tries to distance himself from unnecessary disputes that are not life or death situations.

Jack is just a boy when his father is killed and he goes to live with the Cheyenne Indians. Because he becomes a captive, Calloway's definition would also classify Jack as a renegade, but he does not knowingly turn against white civilization. Instead, he goes with the Indians to ensure his own survival and decides to stay with them after his sister abandons him. The protagonist begins his life story with the declaration, "I am a white man and never forgot it" (1). Crabb's statement clearly expresses where his loyalties lie, which is important because it shows that even though he learns a good deal about Cheyenne beliefs and may even respect some of the main tenets, the fact that he is born into white civilization means that he can never bring himself to convert. The protagonist's feeling about his place in the world is evident in the way that he always says he is passing or pretending to be a Cheyenne. When Crabb is asked why he chooses to leave the Indian camp in the first place, he replies that it is impossible to live as a barbarian unless one is born into that life. The character also criticizes the Indians' arrogance for thinking that they are superior to whites, which is ironic because he as a 
white character does the exact same thing when he decides that whites are superior to other races. The fact that Jack leaves the Cheyenne falls directly in line with Calloway's theories that renegades rarely forget their true identities.

Crabb's refusal to ignore his white origin makes him kin to the most famous renegade character in American literature which is James Fenimore Cooper's Natty Bumppo also known as Leatherstocking. Bumppo is a character that chooses to live with two Mohicans and is almost like a brother and a son to them. He is presented as being the best of both worlds as the ideal frontiersman. Though research shows that Americans expected anyone who associated with two societies to take on the worst qualities of both, this is not true of Bumppo or Crabb. Instead, the two live with the Indians but remain white in their hearts and minds. The two exist on a higher plane than their primitive friends or other renegade characters such as True Son or John Clayton. The idea is important because it shows the author's view that white civilization will always be superior to native civilization.

The six chapters of Crabb's early years with the tribe attempt to describe Berger's version of the Indian way of life before it was drastically changed by incoming whites in a very sensitive tone. The reader's inside view to Cheyenne culture is meant to show that the natives are human beings with many good qualities, as well as some of their own bad qualities, just as their white counterparts do. Crabb describes the Indian camp as a place that might appear to be a bit dirty and smelly, but that has all that a person needs to survive. The Indian characters are presented as being hospitable, family oriented, and cultured in their own way. They are also very connected with violence and clearly enjoy fighting, killing and mutilating their enemies and the main character does his best not to 
negatively judge the Indians because he know he is a white man and does not see the world the way that Indians do. The view of both the positive and negative aspects of the depicted tribe offers a well-rounded and seemingly realistic picture of the Cheyenne characters.

It could be argued that the author's language is an important tool that prompts readers to react to the novel in a certain way. As Jack states in the first few lines, the Plains is a "vast and alien land populated by savages" (21). Though readers may first expect to enter an Indian camp filled with aggressive barbarians, the word usage abruptly changes and the terms that are subsequently used to identify the natives are neutral terms such as Indian, Brave, or Cheyenne. Beginning in the second chapter when Crabb goes to live at Old Lodge Skin's camp, the narrator only refers to the alien others as savages or barbarians a total of five times. In the succeeding segments these words appear less and less. The change in the terms that are used to identify the Indian characters is a small difference, but the author may have purposely labeled the natives in a more positive light to highlight the good aspects of the culture that is being presented.

The opening chapters of the Berger's novel read like a captivity narrative. The majority of what Green designates as the rituals of captivity are included. Several of the studies on renegades discuss the fact that many of the white captives had positive experiences living amongst the Indians. As Green finds, detainees were forced to become Indians out of necessity, but often chose to remain there when the opportunity to return to white civilization arose. Her essay explains that natives employed rituals of captivity that often worked to influence the newcomers: 
The experience of Indian captivity, an utterly transforming one, involved the adoption of a tribal language, the clothes, skills, and mores of these peoples. Even the rituals...were designed to convert Europeans in to Indians. The first terrifying rituals of symbolic revenge on the captive, then symbolic new birth through adoption, name-giving, restoration to a new family, gift-giving, and affectionate welcome and integration in to that family and the Indian society, created a process of change from which there was little comfortable return (32-3).

Berger presents Crabb as a person who begins to see himself as an extended member of the native community and enjoys his childhood as an adopted Cheyenne, otherwise called a white Indian. First, Crabb has a symbolic new birth when he is adopted by the chief, Old Lodge Skins, and restored to a second family after losing his blood relatives. He is called, Voka, meaning "Little Antelope" which is his first Indian name. Jack is also welcomed into Indian society and officially joins the tribe on the first morning in camp when he takes up the duty of tending to the horse herd with the other boys. They also trade goods so that Crabb gains a new buckskin breechcloth, belt, moccasins, and yellow blanket and starts to look more like a Cheyenne. The exchange is a symbolic gift-giving that makes him feel welcomed. The author also makes a point to explain how hospitable the tribe is to Jack and displays the lack of racism on the Indians' part. The presentation of the Cheyenne as a welcoming community that anyone would want to join fits with the modern tendency to view the Plains lifestyle as the most natural way to live and displays the romantic sensibilities that have been incorporated into American Literature more and more throughout the years.

Jack is introduced to the hazards of the frontier in the first chapter when his family's wagon train is accosted, but he has a vastly different experience with violence once he becomes associated with the tribe. Though the American's religion and laws suggest that murder is negative and unacceptable, violence becomes an important tool for survival and a way to gain honors and attention in Crabb's new world. During his years 
with the Indians, he learns to be happy on the frontier and transforms himself from a white captive into a white warrior. One of Jack's first acts as member is to take part in the antelope hunt and help to kill the creatures that will be used to feed the tribe. The act of brutality is also an act of initiation serves to celebrate and ritualize the phenomenon in a way that is not acceptable in the white readers' realms.

Jack takes up arms against his adopted tribe's enemies which include the Crow, Ute, Blackfeet, and Shoshone. The boy is just fourteen years old when he goes on his first raid to steal horses from the Crow. On this venture, Jack and another boy called Younger Bear are attacked by an unknown foe. Faced with a fight for his life, the protagonist ultimately kills the enemy Indian. The narrator presents the killing as an act of selfdefense and admits that he feels no remorse for saving himself and his friends. Readers are not encouraged to negatively judge Crabb for his brutal actions. The Indians accept and encourage violence because Jack immediately becomes a man of standing in the tribe after he kills the Crow. Crabb is re-named Little Big Man because he is little in body and big in heart. It is also worth noting that killing a native simultaneously re-affirms Jack's place in white civilization as he practices the well known convention of Indian killing as a white man's rite of passage.

Despite the fact that Crabb willingly takes part in the hostilities that are associated with Berger's depiction of Cheyenne life, he makes sure to clarify the fact that he does not actually enjoy it and is more forced into the situation than anything else. In his explanation,

I was still young but had killed my man, so if there was a war of any size I didn't find it easy to beg off... There wasn't any other alternative. What I did try, not being actually a Cheyenne, was to kill as few of whoever we was fighting as practicable; that is, I would go all out if it was a defensive action, but slack off if we was carrying the day. I tried, that is, to retain some smattering 
of civilization while doing nothing to jeopardize my barbarian friends. A very thin line to walk. Neither was it always possible to avoid certain savage practices, if you know what I mean. Hell, I guess you don't. All right then: I didn't go out of my way to do it, but I had to take hair now and again. So long as I've confessed that, you also ought to be told that in such cases the victim ain't always dead or even unconscious, and your knife ain't always sharp and sometimes there is an ugly sound as the scalp parts company with the skull. I kept it to a minimum, but sometimes Younger Bear was close by me on the field of battle, offering no choice (80).

In the passage above, the protagonist presents himself as a person who is only willing to turn to violence when absolutely necessary, but also shows that he is vulnerable to peer pressure and ends up giving in on occasion. Still, Jack is sure to separate himself from the natives who take joy in the attack and consider fighting and killing to be a hobby or form of entertainment. The character describes how much his Cheyenne family enjoyed mutilating bodies and says he tolerated the actions and feigned his interest so that he could fit in. Though the protagonist is able to thrive with the Cheyenne, the intrusion of American troops threatens his position in native society.

Just as Calloway points out, renegades are often found to fight against native enemies but not against other whites. In the novel, the Indian chief pulls Jack aside and says "I just wish to say that if you do recall [your former life] and believe riding against these white-skinned ones would be bad medicine, you can stay out of the fight and no one will think the worse" (91). Although the natives in the novel do not see the need for a white captive to fight against other whites, Jack seems to feel that he should help his adopted family. As he explains, "I was making out all right as an Indian and didn't figure on losing any sleep over what happened to my native race when I thought of how little they had ever done for me" (87). Though Jack initially acts like True Son does at the start of his story and says he is unaffected by anti-American violence, readers soon learn that Crabb is more sensitive than he appears. 
On the eave of the fight, Crabb comes to the realization that "the utter annihilation of the paleface on the western prairie wasn't no skin off my arse...but when I studied that out, I never actually saw myself participating in such a massacre" (89). The protagonist's aversion to anti-white violence and the decision not to fight demonstrates that Berger's renegade character is far from being a sadist or a savage like Will Henry's renegade. Instead of contributing to the tribe's efforts against the incoming soldiers, Jack immediately gives up his weapon. The soldier backs down and takes Jack to meet the commanding officer. His hasty change of heart means that the novel moves from being a white warrior's story to that of a white renegade's reintegration to civilization, or what Calloway calls the dilemma of returning renegades. Crabb's return to American life means that he has no family, friends, money, place to live, or acceptable clothing and he is forced to depend on the Army for sustenance until they eventually place him with an adoptive father, a Preacher named Silas Pendrake.

After several years of living on the frontier in a teepee, he has difficulties adapting to speaking English again, living in a house, eating different foods, and following the strict rules of civilized society. Though Little Big Man was treated like a man by the Cheyenne, Jack is still a considered to be a school-aged boy at the Pendrake residence. He does not enjoy the serious, stuffy, and repressed manner of the "American" way of life. At school, Jack is an outcast among his peers and he is teased and beaten up by a bully who calls him a dirty Indian. As the novel continues, Crabb ultimately runs away from their home and decides not to return to the Cheyenne camp.

What I had in my mind on leaving the Pendrakes was of course returning to the Cheyenne. God knows I thought enough about it and kept telling myself I was basically an Indian, just as when among Indians I kept seeing how I was really white to the core. But...I suddenly lost my taste for that venture. I just couldn't see myself going back to a buffalo robe in Old Lodge Skins' teepee. I 
couldn't stand it at the Pendrake's no more but the answer to my problem didn't seem to be returning to savagery after that nine or ten months out of it. Being primitive ain't the easiest thing in the world to get used to if you know better (143).

The quote expresses Jack's feelings of being equally uncomfortable in both societies. No matter what, he can never find a place where he truly fits in and Crabb's distress clearly illustrates the lonely and difficult life that renegades were subjected to in reality and in the arts.

The succeeding chapters present Crabb as a white business man, Squaw-man, buffalo hunter, and Army Scout. His subsequent experience with the Cheyenne comes when several braves attack his stagecoach and abduct his white wife and son. The loss causes Crabb to join forces with the Pawnee, his childhood enemies, to look for the Cheyenne who have taken his family. One of these expeditions ends at a raid where Jack is forced to fight against a former Cheyenne friend named Shadow that Comes in Sight. The two engage in hand-to-hand combat and Jack's connection to Shadow and his tribe is never clearly communicated because the Indian attacks without warning. Shadow almost chokes Jack to death before the he is shot down by a white soldier on the other side of the river. Crabb survives the raid and another series of events lead him back to Old Lodge Skin's camp with a new Indian wife, Sunshine, and her three sisters.

The period when Jack returns to the Cheyenne marks the second period where he lives amongst the natives in peace. Now classified as a Squaw-man because he marries an Indian woman, he is also considered to be a renegade by white standards. Only when the Cheyenne are attacked by American soldiers without warning or provocation at the historic Battle of the Washita does Jack say that he has no problem killing other whites to protect his family. The alteration in the character's view confirms Calloway's theory that 
whites who use physical force against other whites are usually backed into a corner, rather than being inherently brutal by nature. In spite of the fact that he could have defended his family without drawing the reader's negative opinions, Jack never takes part in any of the brutality at the Washita River. He says that he is ready and willing to fight against the American soldiers but that his gun is not loaded and he cannot reach the gunpowder. The protagonist's failure to take action against the white soldiers separates the character from the most vicious renegade characters that attacked whites. Berger's choice to keep Crabb's hands virtually free of blood allows the character to remain disconnected and innocent.

Much like dime novels and other works of Custeriana, the renegade character necessarily needs a reason to be present at the Battle of Little Bighorn and a way to survive the ordeal. The character has an insider's view of the proceedings and survives to tell the tale. One of the main reasons that Crabb does not have the typical characteristics of a white renegade at Custer's Last Stand as described by Dippie is because he enters the fight on the American's side and never wavers. In what may be the most baffling aspect of the novel, Berger sends his character into battle with the soldiers who are out for Indian blood. As the total opposite of John Clayton who tries on numerous occasions to warn the whites and the Indians of impending doom, Jack quickly decides that he does not have any power to affect the outcome. The stories from the protagonist's early years would lead any reader to believe that he has a serious concern for the safety of the Cheyenne, but he fails to convince General Custer to stop the charge. In a complete inversion of Dippie's theory on the placement of white renegades in the fiction of 
Custer's Last Stand, Berger's protagonist starts out with the Americans and concludes his journey with the Indians.

The closing chapters of the novel depict Jack willingly fighting and killing Indians at the famed Battle of Little Bighorn. He never seems worried about accidentally killing any of natives that he knows and loves. At the end of the battle chapter, every single soldier, scout, and civilian is killed with the exception of Crabb. Regardless of the fact that Jack fights on the opposing side, Younger Bear saves him in compliance with a pact that was made when they were boys. Later, when the main character is ashamed for ever agreeing to fight against his former Indian family, he attempts to explain his actions to Old Lodge Skins and is never clear about why he ultimately takes General Custer's side. When Crabb wakes up in the Cheyenne camp of those who had loved and nurtured him as a child, the renegade makes his symbolic return to Indian society after eight years of being away, but does not stay there forever. By the end of his life, Jack has oscillated between white civilization and native civilization at least four times between the ages of ten and thirty-six years old.

There are several points in the novel when Jack notes his dislike or disgust with both Indians and Americans. At the times in his life when Crabb is living amongst the whites, he tends to see the Indians in the same way that other Americans do and mentions how badly they stink or how filthy they are. In contrast with these negative statements, the time that he first returns to Old Lodge Skin's camp after years of being away, he is careful not to stay too long because he feels the persuasive force of Cheyenne life trying to pull him back in. The constant shifts in his feelings make the character very difficult to pinpoint. It might be argued that Crabb's return has obscure or romantic hints about the 
return to the natural way of life where the natives have much to teach the colonizers, which is a very popular theme in American literature of the late 1900s. If the protagonist would have chosen to remain with the Cheyenne for the rest of his days, he would have fit the mold of a white renegade who finally chooses to be an Indian, but the reader already knows that this is not the case because Crabb is situated in white society in his old age.

The non-violent deaths that occur at the end of the novel can be termed narrative or authorial violence because the writer is the one who causes them. Authorial violence is important because it is specifically utilized to further the plot or advance thematic developments. In Berger's novel, the deaths are symbolic and speak to entire groups of peoples throughout history and not simply two of the characters in the plot. The deaths at the end of the story fit with Calloway's theory that white renegades are ultimately fated to die along with their Indian friends. Crabb is present at Old Lodge Skins' death where the chief lays down and asks the governing spirits to bring about his end. The character is despondent over the state of affairs in the world and expresses his idea that the Indians will never have another victory over their white enemies. The wise old man sees the Battle of Little Bighorn as the beginning of the end for him and his tribe and decides that it is his time to go. The Chief simply lies down, asks to die, and never gets up again.

The event of authorial violence can be understood as the symbolic death of the all native peoples which makes sense because all historical documentations of the Indian Wars cite the American loss at Little Bighorn as a turning point when the U.S. vowed to overtake the natives and their lands by any means necessary. Jack Crabb's death at the end of the story where he is an aged man in a nursing home is presented as a symbolic 
passing of all white renegades who must disappear along with the Indians. The main difference is that Crabb does not live out his life as a Squaw man or on a reservation. Despite the hostilities that occur during his early years, Crabb peacefully and painlessly expires in his sleep. Regardless of the fact that the author ends the story in symbolic death for all Indians and renegades, which is a common cliché of the genre, Berger's renegade character is different from some of the other well known renegade characters in American Literature because he separates himself from the racial conflict and hostilities on a number of occasions and always refrains from anti-American violence which fits the theme of the times in the late 1960s when anti-violence is a popular alternative to abusive and racist violence.

\section{Dissecting the Novel: Three Key Representations of Racial Conflict}

Berger's Little Big Man includes bloody physical conflicts between Indians and Americans in the beginning, middle and end of the novel, which serve to envelop the story with violence. Despite the obvious distinctions between the three events, the most important difference is the fact that the protagonist narrates the first and last events from the Americans' side of the conflict and the middle event from the Indians' side. The shifts in the narrator's point of view work to characterize the key players in positive and negative ways and also prompt readers to re-assign the role of hero/villain depending on which side Crabb is on. The first significant aggressive event of the novel occurs in the opening chapter entitled "A Terrible Mistake" when Jack Crabb is ten years old. Readers go back one-hundred years from the time that the narrator tells his story to June of 1852 
when the Crabb family and seven other families form a wagon train to travel along the California Trail. Mr. Crabb and Jonas Troy are the leaders of the expedition.

On this particular day, the train is visited by a group of Cheyenne braves on horseback. Chief Old Lodge Skins and Hump, another warrior, are the foremost of the native assemblage. The narrator explains that the settlers have previously encountered bands of Pawnee and offered gifts of coffee and biscuits, but that this is the first time that they have come into contact with the Cheyenne and all that they have to serve is hard liquor. The meeting starts out very friendly as the groups greet one another and Mr. Crabb offers the Indians a drink of whiskey. The strength of the alcohol and the natives' low tolerance level combine to create a crowd of highly intoxicated Indians. For an unknown reason, Hump tries to attack Old Lodge Skins with a tomahawk and the chief counters with a shot from his old musket that misfires. The hostilities then extend to Jonas Troy and eventually include all of the men. The Cheyenne warriors end up killing all of the adult male settlers as well as one of the boys, and raping the majority of the widowed women. Jack's mother is not raped because his sister Caroline uses her whip to discourage the would-be rapists. The following day the chief and two warriors return to visit the surviving women and children and offer a few ponies to make amends for the white losses. The gift leads Caroline to believe that she is being bought by the Indians and she insists that she and Jack go along with the strangers. At the end of the chapter, the young siblings follow the chief towards the Indian camp and the Crabb family is split up forever.

The Cheyenne slaying of the settlers on the Plains is the first representation of anti-white violence in the novel and involves a small group of Americans and Indians. 
The killings are done with tomahawks, knives and arrows, and result in more than ten deaths. The jarring start to Jack Crabb's life story is important because it serves as an example of what could be termed educational violence. The event is educational because it is the protagonist's introduction to real violence in the West, as well as the reader's first experience with imagined violence in the work. From this moment on, the protagonist learns just how brutal Indians can be and how not to deal with the Cheyenne.

The chapter also teaches modern readers what American life was like on the frontier in the 1850s and shows that trivial misunderstandings between cultures easily led to pandemonium where a fight could break out anytime without warning. Jack alludes to the fact that he has never encountered any type of interracial aggression when he admits to urinating in his pants at the sight of white men getting punishment of this fashion. The statement hints at the notion that he considers himself and the other whites to be superior to Indians and the feeling contributes to his shocked reaction when he sees the natives assume complete control. Berger presents native characters who distinguish between the white men who are adequate opponents and the women and children who are allowed to survive as long as they cooperate and tolerate the sexual abuses. The main character also explains that the bodies are left as they fall, meaning that the Indians do not scalp or mutilate any of the victims because they only implement those rituals at war.

The first chapter is written in the past tense because Crabb is telling his life story years after it happens. The tenses shift at the exact moment where the altercation begins and the events seem to be taking place in current time. Jack describes the start of the bloodshed when he says: 
Hump studies Troy's back for a spell, then pats him with the left hand like Troy had done him, at which the white man turns, hearty as a fellow at a lodge meeting... and Hump plants the hatchet blade into his forehead...Troy looks cross-eyed for a minute at the wooden grip that extends over and parallel to his nose, then Hump withdraws the weapon, letting his victim go over backwards spewing blood (10).

In the quote above, the assault is purposely narrated in the present tense to make the events more realistic for readers who can almost live the events as they occur. The writer first presents the sights of the fight as if they are happening in a silent film because there is nothing to be heard. Just as Elaine Scarry describes in her study, Berger uses the weapons and the bodily damage as the best way to represent the pain or violence. Jack offers more information about the perpetrator's weapon that is a strange cross between a hatchet and a peace pipe.

Later, Hump's nostril is severed and another brave is shot in the back of the head and the explanations are detailed enough to disgust readers. It is worth noting that the protagonist makes a point to describe the Indians' injuries, but fails to describe most of the white men's fatal wounds. The fact that Hump's damaged nostril is hanging from a "little skin string" and that White Contrary's "brains run out like water from a punctured canteen" are such oddly described injuries that they almost seem fake and one wonders whether the narrator has correctly remembered the events of one-hundred years earlier. None of the aggressive action against the native characters is represented in an empathetic tone that might prompt readers to feel sorry for the ailing men. Berger may have excluded examples of Indians suffering because this particular attack is not meant to gain sympathy for the native side or because his powers of description break down in the face of pain, similar to Scarry's theory about the difficulties of representing pain. 
The most effective instance of fictional violence in this portion of the novel

involves a sympathetic victim and the details of the weapon and the injuries that cause his

death. Jack describes the situation where Troy's son tries to avenge his father's death:

Little Troy at this point up and made a desperate move. He run out to his daddy's body, took a butcher knife off a scabbard in his belt, and stuck the side of a tall Cheyenne who was singing a drunken dirge between pulls of a jug.... [The Indian] was in the demon's grip, and raised the lance on which he has been leaning and drove the boy off the ground on its point, which come out the back of his blue shirt directly, accompanied by a great blossom of scarlet. The Cheyenne kicked him free, and he struck the prairie with the sound of a wet rag being slapped onto a bar-top (12).

Little Troy's death necessarily effects readers because the character is still a boy and counts as what John Fraser would call an unnatural victim. The author adds details of the weapon and the wound which help to make the events more real for readers who can imagine what was seen and heard. The representation of death presents the act in a way that will shock readers and make the natives appear as barbarians who would kill a child without thinking twice. Despite the fact that Indian who slays little Troy is responding to being stabbed in the side, the act is still one of the most intense events in the chapter. Another form of physical violence at this exchange is sexual abuse, or rape. Once all of the men are dead, Crabb states that "there is a general movement towards the women" and that the widowed woman known as Dutch Katy and the majority of the women are victimized. The rapes are not represented in a very graphic way and do not mention any pain or bodily damage. There are few very words to describe what happens or how the ladies respond. As Crabb states,

Across he staggered, and Katy knowed it was for her and started to appeal in Dutch, but as after a bit it was clear he didn't mean to kill her, or not anyway until he had his pleasure, she went down on the ground slowly as if melted by the sun, and Hump ripped at the gingham and stuffs beneath until he laid her thick flanks bare, pressing his swarthiness between them, him all dirt, blood, and sweat and coughing like a mule.....this event touched off a general movement by the Cheyenne towards our women...enough was left to mount the widows of Troy and Clairmont, and the Jackson sisters-and if you think there was an outcry on the part of the victims, you are wrong; 
while those were not raped stood watching those who were as if waiting for their own turn, their children clustered around them (13-14).

The fact that Berger includes the violations to show just how bad things really were on the frontier is noteworthy, but it is poorly presented as an occurrence that is not very serious or dramatic.

For the most part, the terms like flanks and mount compare the women to animals and are degrading. The connection of sexual relations with animalistic behavior may also serve to discount the rape because sex is understood to be a perfectly natural activity in the animal kingdom. Though Jack makes mention of the rapes, they are glossed over rather quickly in the story. A real victim of rape endures a life-changing atrocity, but as the protagonist describes Dutch Katy's molestation, the worst part of it is that she gets all filthy and will need another bath. Jack's explanation might show that Berger is not very interested in sending a message about the atrocities of sexual violence, or that he has no understanding of how to adequately express the physical and psychological trauma of rape. The failure in tone could also point to the fact that the narrator was a child at the time of the event and did not have the mental capacity to understand it very well. In either case, the main character is very detached from the sexual violence because it does not happen to him or anyone close to him.

One explanation for the distance between the character and his representation of the day that his father is killed is that Jack Crabb is modeled after the rascal known as Picaro. Picaro is a rogue, dishonest, but appealing anti-hero who goes on a series of adventures where he tricks and is tricked by others, but is not expected to learn or grow from his experiences. Because he is looking at the most negative aspects of each culture, 
any character created in Picaro's mold will necessarily live in a detached world where he is not deeply affected by the occurrences within the story. In his essay, "Thomas Berger's Little Big Man: Contemporary Picaresque", Richard A. Betts explains that the society that is depicted in a picaresque work is "chaotic beyond ordinary human tolerance, but it is a world closer to our own (or to history) than the worlds of satire or romance" (86). In this rather realistic view of society, a picaresque novel or satire utilizes various, seemingly unconnected, episodes within the plot. The first person narrator shares a story that largely critiques society in ways that are often humorous to readers.

The fact that Berger's narrator fits into the genre of the picaresque is easy to see and is regularly mentioned by critics. At least three scholarly articles have been written on this subject alone, but the topic deserves mention in the current study because it helps to explain Jack's detachment from the proceedings at the wagon train. Jack is the ultimate picaresque anti-hero, as he knows intimate details about both the Cheyenne and the Americans and clearly lays out both sides' vices for readers. The position of detached evaluator allows Crabb to keep his distance from the actions and also means that he does not realistically respond to the violence. Though Jack might wet his pants or hide from the aggressors, he is physically separated from what Betts calls the plane of action when he stands far away from the fight. The character is also psychologically removed from the plane of narration as the outside commentator of the killings and rapes that seem to have no affect on his persona.

In the narrator's explanation, the start of the fight includes enough visual details to allow readers to imagine the sight of one Indian attacking another, Hump killing Troy, or two Indians fighting over the whiskey jug. Despite all of the explanations, only one 
death is described before the lights metaphorically dim. The picture fades because Crabb stops describing what he sees and turns to auditory clues about what occurs within the last half of the fight. Jack explains that "From this juncture on, the altercation becomes general and the noise very barbaric: yells, howls, squeals, and screams, the snicker of steel on bone, mushy murmur of flesh being laid open, blast of gunfire, wind of arrows and the whonk of their arrival" (11). The howls and squeals associate the Indians with animals such as wolves or coyotes on the frontier and may suggest that the natives have a carnal nature like the beasts in question.

The noises serve as the author's representation of a horrible cacophony of death on the frontier. The sentence is styled almost like a stanza of a poem and could be labeled lyrical violence because the words flow together so well that readers might not realize what type of carnage is actually being described. The author's choice to represent the altercation in such an artistic way may serve to reduce the horrors that took place and makes the story much less brutal. The fact that no actual words are spoken may go along with Scarry's theory that pain actively destroys language. More importantly, the inspired verse makes a connection between beauty and cruelty, or creation and destruction, which are two central themes of the novel as a whole.

Berger's characterization of the Indians throughout the first chapter includes a big discrepancy between what the white characters think about the Indians and the way that the Indians really act. Crabb's explanation states that the Cheyenne are handsome, tall, straight-limbed, skilled warriors and confidant. The men are also fair, friendly, wellmannered and courteous. The most ironic point is that even after the violence has taken place and the bodies have been buried Jack and the remainder of his family still believe 
that the Indians are friendly and there are several times in the chapter where they say that the braves do not look aggressive. In contrast, Old Lodge Skins and the other Indian visitors arrive heavily armed and carry numerous human scalps, showing that they are closely associated with violence. The chief carries a musket and has a massive scar across his chest which may have come from a fierce brawl in the past. Despite whatever the family acknowledges, the story proves that the Cheyenne are not as peaceful as the Crabbs first imagined. The idea that the white characters are completely out of touch with reality might be social commentary about the ignorance of American settlers when matters of life and death are concerned and fits well with Crabb's role of detached critic.

Though Berger or Crabb never blatantly assign blame on either side of the engagement, readers can infer a number of things from the details in this section of the story. In the most literal sense, the Indians are the instigators or agents of violence because Hump starts the fight by making a move against Old Lodge Skins. From the white point of view, the settlers, women and children are presented as the victims because they are hospitable and friendly to the Cheyenne and are repaid in a horrific fashion. Jack is clear on the fact that the wagon train is made up of virtually helpless, non-violent members who are deeply religious and are only following the "American Dream" of total freedom. Most of the passengers have few weapons and do not know how to fight, which is why they all go down without a struggle. The view of Americans as innocent victims fits with the convention from early American Literature that blames the natives for all of the negative things that occurred on the plains without taking responsibility for any of the injustices committed by other whites. 
Jack is the most perceptive white character in the wagon train because his dualmembership in white and native society allows him to tell the story from a point of view that offers the most amount of information about each groups' thoughts on the situation. Read from the opposite perspective from the one that is detailed above, the Americans are not the victims but the perpetrators. The whites in this narration are too ignorant for their own good and serve liquor instead of coffee to the Cheyenne. Crabb notes that the settlers are insane for even offering it and tells readers that the Indians cannot hold their liquor and are not sorry for whatever happens when they are drunk. The Americans also initiate rough and misconstrued physical contact when Troy goes around slapping all of the Indians on the back in a friendly gesture gone wrong.

Jack knows that the warriors have no understanding of why Troy has handed them a drink and slapped them at the same time, because gift-giving and abuse are not meant to go together. The statements that talk about the native's aversion to alcohol and failure to take responsibility for what occurs suggest that the Indian characters are essentially innocent and should not be blamed for the bloodshed. In other words, the Cheyenne become the victims who cannot be blamed for the aggressive actions that they take to defend themselves. In that sense, the Cheyenne are victims of American stupidity and one could claim that Berger is representing the killings as justifiable violence. As Hannah Arendt notes in her book, "no one questions the use of violence in self-defense because the danger is not only clear but also present and the end justifying the means is immediate" (52).

After the wagon train incident, the second important confrontation in Little Big Man takes place in the middle of Jack's story at the fictional recreation of the Battle of 
the Washita. The real battle occurred on November 27, 1868, in modern day Oklahoma. Historical records show that Custer trained the men for several weeks to withstand the long march in the freezing weather. As Ambrose notes, "he held target practice twice daily, taught the recruits to ride, saw to it that they were properly equipped, and took them a two-week shakedown march to put them into fighting trim" (312). Custer led the men in the dead of winter and located an Indian camp. He had no idea who they were or if they were hostile or friendly, but he decided to attack and destroy. Ambrose claims that it took Custer less than an hour to overtake the camp.

Berger's depicted version of the Washita attack is significant because it introduces General Custer as one of central characters for the last half of the novel. In the chapter entitled "The Big Medicine of Long Hair", Jack is living in a Cheyenne encampment with his wife Sunshine, their newborn baby, her three sisters, and their kids. Crabb awakes at dawn to find that soldiers have launched a surprise attack on the settlement. The warriors rush to hold off the incoming Army and many of the noncombatants attempt to get away via the ice-cold river. Jack struggles to move his loved ones to safety but two of Sunshine's sisters are shot and killed at the very start of the charge. Left with nowhere else to turn, he subsequently hides Sunshine and the newborn baby under buffalo robes in their teepee and goes to help Old Lodge Skins walk through the crossfire and into the water. They wade towards the river bend where a group of Cheyenne women and children overrun and kill Major Elliot and all of his men. After the killings, Jack disguises himself in a cavalry uniform and infiltrates the Army camp searching for his family amongst the captives. Crabb is not able to find Sunshine or the 
baby and he never sees or hears from them again. At the end of the chapter Jack vows to kill General Custer as payback.

The Washita River attack is Jack Crabb's worst experience as white renegade or adopted Cheyenne. The event is important because it brings about the destruction of Jack's Indian family which prompts him to leave the native community for good and produces a reason for Crabb's personal vendetta against George Armstrong Custer that only ends at the climactic Battle of Little Bighorn. The narration occurs in the middle of the novel and sets the stage for the issues that will be re-addressed at the Battle of Little Bighorn. The representation of violence in this episode treats the soldiers who use guns and the Indians who use arrows, knives, tomahawks and a few guns.

Jack Crabb depicts the attack as what can be called organized violence or controlled violence because the attack is very well planned and executed by trained Army soldiers as opposed to the volunteers or amateurs that killed the natives at Sand Creek. The results of the charge show that the native victims are not scalped, mutilated or raped. Many of the villagers are allowed to live and are taken as hostages. Berger places the protagonist in the center of the Indian camp and on the front line of the action since he is one of the first men to see the cavalry charging in. The point of view allows readers to experience the panic and fear that the Indians felt as they were suddenly attacked that winter day. The account fits with the literary conventions of the time because it is sympathetic to the plight of the Native American throughout history.

The depiction of the Washita attack in Little Big Man favors the Indians as the unfortunate victims of white progress. That being said, Berger never offers a detailed explanation of native causalities and the representation of anti-Indian violence is not very 
sensitive. The majority of Cheyenne fatalities simply state that a native "went under", "got his own", or "fell dead". The short and unemotional explanations say little about the deaths and almost allow the reader to overlook the loss without paying much attention. The first Indians to die are Sunshine's two sisters. In Jack's words:

Digging Bear was coming out of the lodge door, carrying my piece and leathern pouch of ammunition. Ten yards still away, she throwed me the rifle and swung her arm back to hurl the pouch, but a little black hole sprung in her broad temple, like a fly had lit there, and she set down dead in the snow. A dozen more slugs snapped through the lodge cover behind her, and when I run inside, I seen young Wunhai had gathered half of them into that warm brown breast I had fondled several hours before, her deerskin bosom all bitten up (244).

Berger's word choice suggests more than just how the women die. Crabb highlights the wounds or bodily damage but says nothing about the pain, the weapons, or the perpetrators. The bullets are actively redescribed as a fly or a slug, which lessens the impact of the killing or connects the projectiles with nature. The author also represents the casualties in an odd way because he states that the hole springs in Digging Bear's temple and that Wunhai gathers the slugs in her breast. The two explanations do not attribute agency to the shooters and make it seem as though the injuries spontaneously occur, or as though they actively bring about their own demise by collecting the bullets. The last time Jack sees them he states, "they was maybe just Indians, but they had been mine and small use I was to them (262). Though this statement is outwardly included to show Crabb's remorse for failing to save his family, he also manages to degrade the women by labeling them as somehow inferior or less deserving of human life when he says they are just Indians. The racist commentary allows Berger's feelings about white superiority to sneak into the account just as they do in the opening event at the wagon train. 
The opposite of anti-Indian violence is anti-American violence. According to historical documentation, the soldiers were not the only ones to take part in the carnage at the Battle of Washita. My Life on the Plains is George Armstrong Custer's personal account of the campaign against the Indians and he notes that the opponents put up a "vigorous and determined defense" and "fought with a desperation and courage which no race of men could surpass" (335). The reality that many Americans were injured and killed at the battle complicates the presentation of the event because it becomes more difficult to take sides or assign blame. Though both groups commit vicious acts in the chapter, the soldiers are following orders and the Indians are fighting for their lives. Readers can take a position against the government for sacrificing the country's young or against the whites for killing natives who are peacefully assembled. Finally, readers can be against the natives who kill and mutilate Elliot's troop.

Berger accurately presents the Cheyenne as being engaged in the violence but gives more attention to the whites who suffer. The most significant death of a trooper occurs when Crabb comes face-to-face with the first soldier. As Jack describes,

A trooper's horse was shot under him and fell into my line of vision... The trooper was hurt...He lay with is left boot at a strange angle from his upper leg. He was a young fellow, hardly beyond a boy, with a newly started mustache. Him and me, our eyes met, and a blaze come into his as they was windows in the back of which somebody just fired a torch, but it was dying caused it and not recognition, for the next instant his head pitched forward showing the back of the skull busted open like an orange. And the Cheyenne who did it, using a wooden war club embedded with a triangular blade of rusty iron, took the lad's carbine and cartridge belt and dashed for the river (245).

The passage above is successful because Berger uses each of the methods outlined by Scarry in The Body in Pain to represent the violence. There are details about the victim's collapse, his bodily wounds, mention of his age, of the look on his face just before he 
dies, the weapon that causes the injury, and the Indian that does it. The explanation is one of the numerous times that Crabb mentions the young age of the Americans and highlights the reality that many of the soldiers who died for their country were barely grown-men. The loss of several American boys is meant to pull at the reader's heartstrings and symbolically memorializes all of the young men who died at the actual event.

The key example of anti-American violence appears at the attack on Major Joel Elliot and his command. In fact, Berger pays more attention to the attack in fiction than George Custer, Nathaniel Philbrick, or Stephen Ambrose do in their non-fictional accounts. The narrator places Jack very close to the struggle, but does not include him in the fight. Instead, Crabb stands by as the Cheyenne kill, strip and mutilate the entire group. Jack approaches the site of the carnage to find Younger Bear working on one of the dead Americans and is recruited to help pull off his scalp. As Crabb describes, "I knelt and took hold of them light-brown, rather fine-textured locks of the dead white man. I think he was right young. His mouth was strained open as if in a silent cry ...at length his skull cover came free, and I was obliged to Younger Bear for taking it quickly from me" (252-3). The graphic and brutal parts of the story are important because they explain what really happened in history, as well as presenting the Indian point of view of Elliot's demise. Though readers may be disgusted with the Cheyenne women or children for the severe acts that they commit, it is also clear that the natives are acting in response to the unwarranted attack by the Army. The charge ends as a mid-scale assault because George Custer only devastates one Indian village and does not move on to the 
surrounding villages. Berger's account of this historic event is added to offer an explanation for the way that the Indians act so aggressively at the next serious encounter.

Chapter twenty-eight, entitled "The Last Stand", opens at the Battle of Little Bighorn in June of 1876. The battle is important because it offers Berger's account of General Custer's last fight which is the crowning moment of any work within Custeriana. The fictional battle begins when the General and a portion of the $7^{\text {th }}$ Cavalry charge the native camp on the river. A startling number of Indians arrive from all directions and soon engage the men. The U.S. recruits have difficulty maneuvering the horses on the terrain and firing the guns that jam when they overheat. The soldiers are wounded and start to die successively in troops.

Jack stays close to General Custer as he commands the men from the summit of a ridge on the highest point of the battlefield. The soldiers soon realize that they are surrounded from every angle and start to execute their horses to make protective breastworks out of the carcasses. The Americans continue fighting for their lives and hold out a hope that Captain Benteen or Major Reno will arrive with reinforcements. Help never arrives and the men continue to perish. The soldiers dwindle from the original twohundred odd men who start the charge, to one-hundred, to forty, to twelve, and finally down to the sole survivor-Jack Crabb. Jack watches as all of the men in the command die, the foremost being General George Custer. The protagonist sustains several wounds but is saved from imminent death when Younger Bear knocks him in the head and carries him to safety.

The Battle of Little Bighorn is the most intense occasion of violence in the novel. The climactic battle contains the largest amount of participants and results in the deaths 
of about two-hundred Americans and an estimated fifty Indians. Though history shows that natives were wounded and died at the real battle, the fictional account does not focus on anti-Indian violence. Instead, Jack says that the natives suffer casualties but that the Americans can never tell when they have hit a target because there are such a massive amount of enemy combatants on the field. As previously discussed, Jack Crabb is an active member of the fight.

The author's decision to attribute overly-aggressive acts to the main character is noteworthy because it shows that the situation is so bad that Crabb is forced to choose a side and take up arms for a cause. In this fight, Jack decides to shed the blood of his former family and their comrades. He kills his horse and shoots several Indians. Jack's shoots a nearby Indian and says that "the muzzle was damned near his nose when I fired, and his brains was blasted out before his eyes knowed it" (414). The shooting is very similar to the incident at the start of the tale where Hump tomahawks Troy in the forehead. The connection between the first and the last act of physical violence in the novel closes the circle of the violence in Berger's plot and may suggest that the history of the West can easily be summed up as a face-to-face clash of races that ends badly for both sides.

Jack says he shoots and Indian but does not know whether he dies or survives because the Indians remove their wounded men. Other than these few comments, Indian suffering is glossed over and is virtually non-existent in Berger's version of the story. The lack of consideration of the Indian experience of the Battle of Little Bighorn is noteworthy because that is the only side of the clash where actual survivor testimonies are available. Berger's choice to ignore one side of the battle is also important because it 
means that the chapter is not sympathetic towards the warriors who take part in the ambush and that the author is writing from a biased perspective that only works to represent the ordeal from a soldier's point of view to make audiences feel for the white men who gave their lives fighting for the future land of the United States. Although the author may have started out wanting to portray the native culture in way that would celebrate the peoples who were overtaken and abused by encroaching white civilization, the battle chapter almost negates the author's best intentions by flipping to the compassionate tone that highlights Custer and the other men's suffering and provokes readers to see the fight as a crime against white humanity. The fictional Battle of Little Bighorn inevitably includes several examples of soldiers in distress, or anti-American violence.

According to Crabb, the soldiers storm the camp and are met with a barrage of arrows and bullets fired by Indians who are hiding in the coulees and gulches. Many of the men end up losing their horses when they are either killed or scared away by the noise. The short description of the first victim of Custer's Last Stand fits with the patterns of the other hostile occurrences in the novel. In this segment individual deaths are described in a similar fashion to other parts of the novel. Jack says that half-white, halfIndian Scout, Mitch Bouyer, is hit by the initial gunshots of the charge and describes the dark stain of blood on the man's shirt. The speaker cites the weapon, the bodily damage, and also notes that the victim feels no pain and does not seem to react.

Other explanations of death are more graphic. Speaking of the stream of Indian arrows, Crabb remembers that "them high-arching volleys was on the increase, hundreds of steel points descending through the murk, like it was raining razors. Fellow near me, 
sprawling flat, got stapled down in two, three places, but never killed until threshing about to free himself he fetched his head high enough for a bullet, collecting several, expiring still fastened" (406). The explanation describes the weapon in detail and a vague description of the wounds. Only the fact that the man was threshing about suggests that he is in pain.

One of the worst statements describes the remainders of a troop who try to rush up to where Jack and Custer stand. Many are shot in the back and belch blood on the other soldiers helping them up into what he dubs a "growing mortuary" (408). The thought of men spewing blood all over their comrades is a sickening image. The author also describes the appearance of the soldiers' corpses after the Indians are done with the abuse and disfigurement. Flies are feasting on the open flesh. The native men and women have mutilated all of the bodies. Readers are prompted to feel compassion for the loss of American lives in this famous military failure.

When the Army encounters a gigantic group of Indians on the Montana Plains, the narrator is taken aback by the difference in the ways that the natives approach the battle, as opposed to previous conflicts. The admission works to separate the other aggressive fictional accounts, such as the slayings at the wagon train and the Washita River Massacre, from the Battle of Little Bighorn. Jack explains, A peculiar reverse of roles took place that day upon the Little Bighorn. Reno had been sent to charge the village and instead was himself charged. Custer, going to envelop the enemy, had got it done to his own self. In their last great battle the Indians fought like white men was supposed to, and we, well, we was soon to arrive at the condition in which we had planned to get them, for this wasn't the terrain for cavalry and our order commenced to dissolve somewhere along that flight (402).

Similar to Sunshine's sisters' death, the author arranges the words in such a way that agency is never attributed to the aggressors. Instead of writing that the Indians "charged 
Reno" or "enveloped Custer", where the natives actively bring about an intended result, Crabb states that both men "got it done" to themselves. The creative use of language makes it seem as though the Americans have brought about all of the proceedings on their own, acting as both the victims and the victimizers. If readers are to understand the passage in this light, the statement may suggest that Reno and Custer are to blame for their tactical failures and for the entire loss at the Battle of Little Bighorn.

Read from another perspective, the object may be to remove the Indians from the account and credit them little to nothing for what they accomplished that day. Crabb's theory that the Indians perform the way that whites should suggests that they simply duplicate American battle tactics and also works to pull attention away from the natives. Several historical studies would disagree with Berger and instead propose the idea that the natives actually played to their own strengths by overtaking the soldiers as they normally stalked animal game on the very same terrain. The author's misleading presentation of the battle as a role reversal may also suggest that winning a battle is an essentially white activity, whereas losing is an Indian activity. The few sentences about the Indians' tactics describe Berger's theory that the Indians prevail by using organized violence. Jack's story emphasizes the fact that General Custer and his men lack control from early on. In contrast, the native opponents are described as being very well managed. Just when the men are surrounded and the situation heightens to the most desperate point, Crabb says that the warriors carry on "without disorder, a directed passion if you can imagine that, the wild and merciless fixed upon a single aim and undistracted. They was Cheyenne and they was at the center of the world" (404). The quote shows that the Indians never lose their restrain and slowly eliminate the opponents. 
Berger, via Crabb, seems to suggest that organized violence leads to success because the very same approach at the previously fought battle at the Washita River worked for the soldiers.

The author's language in this particular section diminishes the harsh reality of the situation and significantly softens the blow by presenting the fight in a more delicate light that makes no mention of weaponry, blood, pain, or death. Berger's decision to disassociate the account from graphic violence is notable because the climax of the novel becomes a symbolic representation of a huge clash in history that sends certain messages about the time, instead of a gross depiction of what really occurred in documented fact. It should be noted that the climax of the novel sees a dramatic change in the author's mode of representation. First, the language used to describe the Indians dramatically shifts. Jack Crabb calls the fighting Cheyenne and Sioux savages nine times within the chapter, which is more than any other portion of the novel. A savage is understood to have a beastly nature and is more closely tied to animals than humans. The designation has a negative connotation and stresses that the enemy is overly aggressive, hostile, and vicious. The narrator also depicts the warriors as snakes several times. Crabb says that they slithered towards them, that they "squirmed through the tall grass below", and that "their serpent heads popped up briefly" (407). The characterization connects the native combatants with reptiles and may point to Crabb's new feelings about the Indians as he relegates them to a sub-human category. The reference to snakes might even tie into Genesis in the Bible where the serpent is the one to initiate conflict and disharmony in the Garden of Eden. 
The language in this piece also moves from literal representations of violence to figurative representations that only appear in this chapter. Instead of relating all of the gruesome details of the killings, the author uses at least five metaphors that characterize the native force as a body of water. First, Jack says that the Indians "came out of the grass in a great naked brown wave" and wash over Calhoun and his troop (403). Then he states that "savages would well out of very nook, drowning another portion of the command" (403). Crabb even describes himself as "riding a splinter on a roiling ocean of hostiles" and standing on a "diminishing island in a river at flood" $(408,412)$. In this way, the action is portrayed as moving in tides similar to the way that water ebbs and flows and an entire troop is killed as quickly as a wave washes over the shore. The descriptions likening the natives to a rolling ocean are similar to some of the testimonies of the Indian participants that are found in non-fictional accounts of the battle. Berger might have added these images to make the deaths appear as something that is an act of nature, which may or may not place blame on the Indians. Native arrows and bullets are actively redescribed as environmental elements such as rain, hail, or sleet. The tactic can be labeled organic violence because it ties the natives and their weapons with the natural world and suggests that the Army soldiers cannot fight Mother Nature.

The legends of Custer's Last Stand often name the General as the very last soldier to die because he is supposedly the most resilient opponent and the fact that he holds out longer than any of the other white characters symbolically raises him above everyone else. The widely held ideal of George Custer as the last man to go down is also evident in the majority of paintings, pictures, and films that depict the General standing amidst a pile of dead soldiers, waiting to accept death. Despite the popular conventions of the 
genre, Berger opts for a more realistic explanation which says the General is able to avoid the initial scuffle because he is waiting at the most safe part of the battlefield. In Crabb's words, "we in Custer's party was now upon the summit of the ridge, farthest distant from the enemy as befits a general is defensive action...so there was much to watch of the meanest kind of sight, and nought to do at that range" (403). In the end when there are no other troops to cover them, Custer's men come under attack and the author describes the General as one of the last twelve men to die. Although Berger does not fall in line with the convention of naming the General as the last man standing, the protagonist still celebrates the world historical individual for his courage and strength in the face of adversity. The way that the Custer character accepts his death like a real man is the action that ultimately changes Jack Crabb's view of the General and wipes away the revenge plot. Readers are meant to follow suit and finish the novel with a positive view despite Custer's faults and professional failures.

Little Big Man is a multi-faceted work that deserves recognition on many levels. The book was published in a time of global change which saw the emergence of real and imagined violence in society and the arts that significantly affected the author's work. The new environment in 1964 might have left Berger unsure about how to treat fictional violence. In this novel, the author elects to take a cautious approach and the imaginary violence is always present, but is not represented in to the most brutal, graphic or revolting ways. Little Big Man also makes a concerned effort to value to the Plains Indian lifestyle by offering many of the positive aspects of the culture and being very faithful to the earlier studies conducted on the tribes that are depicted. Berger works to represent "frontier violence" that is true to historical fact, but rarely denounces the Indian 
characters as vile savages who lack humanity. His research also included of the "Indian side" of the story. He reportedly read native accounts in an attempt to offer a new version of the "Old West" that celebrated and memorialized the natives from history. That being said, the renegade protagonist ultimately chooses the white society in every novel that was reviewed for the current study. It could be argued that Little Big Man is representative of the time and place in which it was created and speaks volumes about the way that Americans viewed violence, war, and racial conflict in the mid-1960s by showing an emerging sensitivity with the brutal events that led Americans to where they are today and that work has been carried on by writers ever since. Beginning in the early 1900s, the U.S. film industry effectively starts up where literature leaves off and treats imagined violence in way that has also changed with the times and has a big influence on America's view of its history. 


\section{FILM: Turning Violent Words into Images}

The fact that movies have always been an immensely popular form of entertainment gives artists the power to communicate with a larger audience and share their messages about society, war, racial conflict and violence in America. The film industry's popularity and widespread viewership spans the globe and reaches multiple levels of society, both academic and non-academic. In his book, Violence in the Arts John Fraser asserts that "these days movies are what classical Latin literature once was to educated people- the one cultural topic that they almost all have in common and feel strongly about" (ix). As Fraser's statement suggests, films arguably have more power to influence public opinion in today's age than any other art form. Much like American novels, films regularly treat historical events like wars. Artistic license allows filmmakers to add, omit, or change several elements of the traditional accounts to replace established legends. False as any of the creative accounts may be, critics agree that audiences tend to accept the stories in movies as factual representations of American history. Research shows that the film industry has had an imperative role in promoting Custer's Last Stand and the widely held ideas about this event. Philbrick draws attention to the importance of "Custer films" in his own life when he admits that his initial lessons about the Battle of Little Bighorn came from the film Little Big Man, as opposed to the history texts at school.

Visual treatments of General George Armstrong Custer's life and death began in 1909 and since then at least forty major motion pictures have been produced. The ways that Custer has been treated in film throughout the years is closely tied to the way that he 
has been treated by writers. Critics have pointed out the time periods when major changes in the representation of General Custer have changed. The movies from the early 1900s mirrored the early literature because they presented the heroic dead-lion character; much like the one that Whittaker and Mrs. Custer had zealously worked to spread. The Custer war films were often created to celebrate the country's legendary characters in an attempt to unite American against external enemies. The celebrated story about a brave hero who fights against all odds is an important plot that has its place in the late 1800s when the armed forces are working to secure the plains and also in the 1900s when Americans are overseas in global combat. Raoul Walsh's They Died with Their Boots On was released in 1942 and is a very well known example of the pro-Custer theme in American cinema. In his book, Custer: The Man, the Myth, the Movies, John Phillip Langellier states that the film epitomizes the first three decades of the General character on the silver screen and "was to become the pinnacle of Custer's celluloid image" as a courageous hero who serves his country above all else (48).

The story begins at West Point in the year 1857 and chronicles the early adventures George Custer, played by Errol Flynn. The protagonist is portrayed as polite, confidant, enthusiastic, and eager to be famous. He is also a clown and a trickster, but his hard work and determination help him to succeed. Custer disobeys orders on several occasions but always comes out on top with a combination of talent, luck, and pure disregard for any obstacles that stand in his way. He never acts like he is weak, afraid, or sorry. After graduation Custer gains power and respect by fighting in the Civil War. Although this is the first hostile occurrence in the film, the war has a very mild tone and does not show Americans from the North and South actually fighting. The battle scenes 
are mostly of men riding around, whooping and hollering, with distant bridges being blown up in the background. The director's choice to omit the violence from the Civil War works to pull focus away from one of the most divisive events in American history and pushes straight through to the other notable events in the hero's life. The real George Armstrong Custer spent fifteen years in Army where fighting was his profession. My Life on the Plain clearly documents George's numerous experiences with violence. Despite the facts of the situation, the director ignores the Battle of Washita and other skirmishes where the Custer and his men wreak havoc on the Indians. The only reference to Custer's ruthless attack at the Washita River is an eight second shot of Indians and soldiers riding through a blizzard that quickly cuts to another shot months later when the winter is already over. The lack of anti-native violence in the film offers a biased or onedimensional representation of the Indian Wars and hides the reality of the blood that was spilled by Americans in the name of progress. The entirety of the film before the climactic fight purposely disassociates General Custer from racial conflict to portray the protagonist as a blameless hero going into battle. Far from being the famed Indian-fighter of legend, viewers of Walsh's movie never see the hero harm the natives, or anyone else for that matter. Custer's most violent action in the majority of the film is a push or a shove here and there. The final scene is the only part of the film where George Custer actually engages in hand-to-hand combat.

The principle Indian character is Sioux Chief, Crazy Horse, played by non-Native American actor Anthony Quinn. Crazy Horse has very few speaking parts but generally represents natives as being peaceably inclined towards whites as long as they are allowed to remain in their homeland. One might go so far as to argue that the dialogue of the film 
is written in a way that presents General Custer as a self-appointed guardian of all Plains Indians, as he is the only character who is interested in their rights and well-being. The General deals very nicely with Crazy Horse when he attacks the convoy and admires the Indian for his excellent horsemanship. Custer also adds a clause demanding better treatment for the natives in his dying testimony which suggests that this was one of the causes that he willingly dies for.

Walsh's choice to celebrate the Army and characterize the Indians as victims of white supremacy leaves audiences in search of someone else to blame. Therefore, the villains of the film are two ranking officers and a civilian businessman who are greedy and immoral. The men open up shop at the Army posts and sell liquor to the enlisted troops as well as guns to any Indians who can pay. The three characters represent corrupt officials and investors who are responsible for the loss of human life on both sides of the conflict as a result of their choice to prioritize financial gain over the best interest of the nation. They Died with Their Boots On vilifies these types of men and shows that they always fail in the end.

Walsh's most significant addition to the Custer legend takes place in the scene of the morning before the final battle. Custer meets with a scout and learns that the Indians have already overrun General Crook's column and are headed to attack General Terry and his men. Though the scout explains that they are outnumbered and recommends that they retreat, Custer chooses to fight in order to try and save the other column that is under threat of being ambushed by the Indians. The fact that he knowingly goes into a losing battle shows that he is a hero for giving his life for the country. The film could also serve as a cautionary tale about the price that soldiers pay for the government's errors in policy. 
The treatment of the Battle of Little Bighorn lasts for over six minutes and is the lone combat scene in the movie. Though there is hardly any bloodshed, soldiers are killed with Indian arrows or tomahawks and a large number of Indians are shot off of their ponies. The representation of violence is intense because the camera is placed close to the action and audiences watch as one soldier after another is taken down by the enemy. Walsh's film is a very effective agent of nationalization that encourages audiences to venerate war heroes. Custer's death is presented in a way that glorifies the leader and his men for their courage. True to the most popular legend of the battle, the film portrays General Custer as the last man standing. He bravely awaits his death with saber in hand and is ultimately killed by Crazy Horse. The final scene where Custer's dying declaration denounces the white merchants as villains and demands protection for the Indians concludes the story in a way that justifies the sacrifices that were made.

\section{$\underline{\text { Subsequent Characterizations of George Custer in Film }}$}

They Died with Their Boots On (1942) was the last film to portray a decidedly positive version of General Custer. American's views changed after the world events in the 1930s and so did the representation of Custer in print. Although writers had moved on to the debunking trend and created a completely negative treatment of the General, Paul Hutton finds that "filmmakers, faced with producing for a much wider and often less sophisticated audience than that of the historians and novelists, found it safer to concentrate on swashbuckling adventure than on psychological analysis" (34). The first 
film with a negative slant on the Custer character was not released until the cinematic trends caught up to the literary trends in 1948.

Fort Apache was produced by famed Western Director, John Ford. The film does not include any direct references to General Custer or the Battle of Little Bighorn, but addresses the subject in a creative way by alluding to the legends of the infamous event. Ford characterizes the protagonist, Colonel Owen Thursday, as an arrogant glory-seeking commander who is relegated to what he considers to be an insignificant post in Arizona territory. The man appears to have very few redeeming qualities and quickly becomes an outcast at his own fort as a result of his arrogant attitude and condescending manner. The commander gives little importance to the issues regarding the local natives and only finds interest in the venture when he realizes that a major success could land his name in the newspapers.

Though they are working to send completely opposed messages in their films, Walsh and Ford both choose similar types of antagonists for their stories. The villain in Fort Apache is a post trader named Mr. Meacham who is employed as a government representative in charge of the local Indian reservation. The scene that introduces the character also reveals that Meacham has done more to harm the natives than to help them because his merchandise consists mostly of an extremely low grade of whiskey and long range rifles, but little of the supplies that the natives need to survive. Within a two minute dialogue, the man calls the Apache savages twice, a fact that underscores his racist ideas and indifference towards the people that he is charged to protect. It becomes clear that the only reason the agent wants the Indians around is to sell his shoddy goods. Viewers also learn that the Indians have become fed up with the dreadful living conditions and have 
already left the reservations and fled to Mexican territory. The representative of the government is disliked by all of the Army soldiers and the only difference is that Colonel Thursday protects the man from abuse because he is U.S. employee, while Captain York, (John Wayne) the second in command, is ready to assault the man for his terrible treatment of the Apache. The scene at Mr. Meacham's reservation is included to show that Thursday has no interest in the Indians' well-being and basically falls in line with the other crooked government workers, while York continues to stand up for the Indians. The scene also denounces inside enemies that work against the best interests of America as a whole and suggests that men like Meacham should be sought out and stopped.

The Apache Indians are represented by the chief Cochise who is a stoic character and has very little back-story or introduction. It could easily be argued that the Indians are not presented as significant players. Firstly, the natives have very few appearances or lines and the main Indian is the only one who is allowed to speak. The single scene with dialogue includes less than one-hundred and fifty words uttered by Cochise. Secondly, the Indians do not appear until the mid-way point of the story and are never portrayed in their own village which means that there is very little attempt to present their authentic point of view of the events. The audience receives much of its information about the Apache from Captain York who is a white soldier that is very sympathetic to the Indians' plight. Ford seems to use the Apache as a faceless group of actors that oppose the antihero in his failed plot to dominate the land. It is worth noting that Cochise's few words do have an impact on the film because they explain why the Apache have left the reservations and broken the Government's rules. The main points are as follows: 
Chief Cochise: The Apache are a great race, proud, and we were not born to live as slaves. Your nation started a war and has never conquered us, but it is not good for a nation to be always at war. The young men die, the women sing sad songs, and the old ones are hungry in the winter. So I led my people from the hills. Then came this man (Meacham), a wicked man who lied and spread sickness and vices in my nation. He is worse than war; he not only kills the men, but the women, the children, and the old. We looked to the great white father for protection, he gave us slow death. We will not return to your reservation while that man is there or anyone like him. Send him away and we will speak of peace. If you do not send him away, there will be war. For each one of us that you kill, ten white men will die.

Colonel Thursday: I find you without honor, you are not speaking to me but to the United States Government who orders you to return to your reservation. If you have not started out by dawn, we will attack.

The meeting scene is important because it is the only time in the entire film that the director treats the Apache very sensitively. Just as Raoul Walsh does in his film, Fords' Indians are characterized as victims who turn to violence only after all peaceable negotiations fail on account of the U.S. Government's maltreatment. The fact that the Apache are not to blame for the ensuing battle only leaves Colonel Thursday to take responsibility for the attack that will occur at the end of the film.

The lone fight scene of the film occurs at the reconstruction of Custer's Last Stand. In the climatic battle, the commander ignores all recommendations against friendly treatment for the natives and goes ahead with a charge that sends them into a barrage of enemy bullets. Thursday leads the attack and is the first American to be shot down. Although he is wounded, he forgoes an opportunity to escape with Captain York who offers to help. Instead, the Colonel rejoins his troop and he and his men go to their deaths during the Apache's final charge. Both the characters in the film and the viewers know that Thursday makes a grave mistake by fighting the Apache and that he does not have to die that day. Despite that fact, Ford's closing scene communicates the idea that the Army lives on through legend and that no one who dies fighting dies in vain. The lesson from Fort Apache was important in a world that was becoming more and more 
hostile and where citizens might be called upon to serve at any time. The film teaches Americans that they can make contributions to the American cause that will be highly celebrated by generations to come.

\section{The Vietnam War and George Custer in Film}

Fort Apache was the start of a new trend of anti-Custer films that continued from then on. In the late sixties after the details of the Vietnam War were exposed, popular opinion strongly opposed idealization of former American heroes, governmental abuses of citizens and residents, and racist policies designed to control specific groups of the population. Filmmakers who wanted to speak out about relevant issues of the war added messages into their movies. Research suggests that American audiences were not ready for actual portrayals of the Vietnam War while it was still taking place. Alexander Bloom notes that no movies representing the actual war were made until the event was officially over. For this reason, the films that were created in the 1970s took a more sensitive approach by presenting remote periods of history that could still connect with the current issues of the time. As a famed failure, George Custer's battle against the native Indians in the West was a story that was easily transferable to other battles against other natives around the world. The 1970s Western films, often called Vietnam Westerns, were all created to protest of the country's role in the ruthless violence in the East. In these treatments, General Custer was depicted as the villain and the Indians were the protagonists who tell the stories of Western expansion from a previously ignored point of view. 
The first example of a Vietnam Western, A Man Called Horse (1970), was directed by Elliot Silverstein and is set some time after 1820 in Sioux territory. The opening text attempts to validate the film by presenting it as a semi-documentary that is largely derived from the artistic works of George Catlin and other eye witnesses of the period. The movie is a noteworthy member of the Vietnam Westerns because it includes only a few white characters, very little white versus Indian conflict, and never portrays the armed forces. Instead of showing U.S. governmental abuses to gain sympathy for the victimized Indians or Vietnamese, Silverstein works to humanize the Sioux by portraying his idea of "authentic native culture" before it is negatively affected by encroaching white civilization. The director aspires to represent the native community as one that is closelyknit, respectful of its elders, and bound by tradition. The Indian characters are human beings who have likes, dislikes, values, and the right to a peaceful existence. The protagonist, John Morgan (Richard Harris), is a British Lord who travels to America for vacation. John is a gentleman of high social standing who is represented as being superior to the low class, uneducated, idiotic and intoxicated whites that appear in the first scene.

The film is cliché in the sense that it opens with an aggressive encounter between whites and natives. A group of Sioux attack Morgan's campsite to steal their horses. The Indians quickly kill and scalp the three hired men. Silverstein is the first director in this selection to focus on the Indian practice of scalping and even goes so far as to show the characters in the act. The bloody scalp and bare skull are one of the most brutal sights of the entire film. Scalping is a native ritual that seems to be highlighted more and more in the film industry as time goes on. Nowadays, no "Indian movie" seems to omit practice of scalping because the brutal act leaves a lasting impression on audiences. In Kevin 
Costner's 1997 film Dances with Wolves, one of the characters is shot with arrows and scalped alive by a Pawnee. Although the incision is not shown on camera, audiences hear the victim as he screams out in pain.

In Silverstein's film, the Sioux capture Morgan whom they ridicule and abuse. Once they reach the camp, he is tied to a post and is offered to the chief's mother as a slave. The most noteworthy aspect of A Man Called Horse is the representation of the Indians as being intimately associated with physical violence. Morgan proves that he is a white renegade when he brutally stabs and scalps two Shoshone intruders. He is congratulated for his kill and wins two horses as his first step towards being fully integrated into the tribe. The film also emphasizes the Sioux practice of self-mutilation. Tribe members in mourning chop off their fingers and cut large slits across their chests. Men of high standing are expected to endure the an agonizing ritual when they are suspended in the air from a rope tied to bird claws that have been dug into the men's bare chests. The main character begins to hallucinate from the pain and eventually loses consciousness.

The climax of the story depicts the Shoshone's destruction of the Sioux encampment and its inhabitants in just six minutes. The hand-to-hand combat is fierce, but does not noticeably differ from the battle scenes in other films. John fills the role of white warrior when he leads the native archers and single-handedly kills several Shoshone braves. The attack ends with the deaths of virtually every central character in the film, including the chief and John's Indian wife. The final scene shows Morgan as he says goodbye to his Indian friends and returns to white civilization where he truly belongs. The fact that he finds a new life with the Sioux, but ultimately decides to leave, 
follows Calloway's theory that renegades never forget they are white and only treat captivity as a temporary departure from everyday life. Silverstein's film, A Man Called Horse, shows viewers that Indians and whites have a shared humanity and encourages unity between the two. The notion that the natives are different and have ways that are sometimes hard to understand connects to the reality of the time when the Vietnamese and Americans are poles apart. Despite their differences, the film and argues for humane treatment of all peoples.

Soldier Blue is another Vietnam Western that was released in 1970. Before the film begins, the text introduces it as the representation of "the dark side of the human soul [where] blood lust overcomes reason" and reflects on the fact that everything that is portrayed actually happened in history. Director Ralph Nelson creates his own Vietnam Western with multiple scenes of atrocious physical and sexual violence to denounce American crimes and make viewers side with the natives. The main character is a young Private, Honus Gent, played by Peter Strauss. He is a member of a volunteer militia affiliated with the United States Army. The fact that the boy has newly enlisted suggests that he does not have a clear idea of the way that things work on the frontier and that he has never come into contact with a real-life Indian.

The director tarnishes the American characters from the very start and the first piece of dialogue in the film is one of the Americans commenting on the size and shape of a woman's breasts. During the short time that these white soldiers in Honus' troop are alive, they appear to be perverted and sex crazed pigs of low moral fiber. The director works to distinguish the seemingly innocent protagonist from the other volunteer soldiers. The action in the film begins when an Army wagon train escorting a white female and a 
trunk of U.S. currency is accosted by native warriors. The violence is very graphic. Viewers see a soldier who has a huge hole shot into his face and the Indians proceed to kill, scalp, and burn every living thing. The female passenger and Honus Gent are the only whites to survive. They hide by a tree and watch as the Cheyenne entertain themselves with the mutilations and plundering. One of the harshest examples of the Indians' attack reveals a dead soldier's body with the arm sliced off at the shoulder. Gent is disgusted with the Indians' sadistic behavior and solemnly mourns the loss of his comrades. The event sets the stage for the rest of the story that will be very graphic in nature.

The female passenger is identified as Cresta Maribel Lee (Candice Bergen), a renegade who is kidnapped by the Cheyenne and later becomes Chief Spotted Wolf's wife. The woman lives with the Indians for years and openly sides with the Cheyenne and says they are being unjustly exterminated. She is very sympathetic to the native point-ofview that says that nothing that the Indians have done thus far can be any worse than the Army attacks on natives. She is seemingly unaffected by the soldier's deaths at the start of the story. Cresta's characterization fits well with Calloway's theories about renegades because she continues to think of herself as a white. Cresta's dual-identity allows her to see the best of what Cheyenne life has to offer, but she also sees the intrinsic differences in both cultures and chooses to return to American society where she feels she belongs. As she explains: "I am not a Cheyenne, Soldier Blue, and I never will be, but I can tell you right now, I'd rather be one than any rump butt soldier of any bloodthirsty army you can name" (Candice Bergen). 
The villain is a white American trader who makes money selling guns to Indians. The man is disgusting and low-class. He betrays the U.S. government by selling weapons to their enemies and profits from the natives who end up attacking and killing whites to steal the money that they use to buy the rifles. Once again, the message seems to be that Americans are often their own worse enemies when they let greed guide the way. The central Indian character is Chief Spotted Wolf. The man does not have a large part in the film, but appears to prefer peaceful relations with Americans who have given him a medal and told them where to situate their camp.

The climax of the film portrays Ralph Nelson's version of the U.S. Government's dealings with the Cheyenne at the Sand Creek Massacre of 1864. Historically, the events at Sand Creek are one of the reasons why the Indians are said to act so aggressively later on when they encounter the white troops at the Little Bighorn. Despite that reality, this film flips the two events around and Gent says that he joins the Army to get revenge for his father's death at Little Bighorn. The small change in the chronological sequence of the battles justifies Gent's initial hatred of Indians, as well as the Army's actions in the end of film because they all appear to be retributions for Custer's Last Stand. It can be argued that the fact that the director gives Americans an excuse for the occurrences at Sand Creek devalues the final scene of the film and the message that he is trying to send.

When the Indians and the Americans clash about the Government sanctions that have been followed or ignored, it is clear that the Indians have done all that they have been asked and yet they are still treated as hostile enemies of the state. Private Gent and Cresta both try to intervene to no avail. The commanding officer, Colonel Chivington, has no understanding or respect for Indians and ignores any mention of peaceful 
negotiations. The leader sees Spotted Wolf ride out with an American flag tied to a white flag of truce but still gives the order that the military cannons begin to fire at the camp. The intense struggle that ends the film lasts for almost fourteen minutes which is longer than any other fight scene of all of the films reviewed in the current study.

The combat scene starts out with shots that alternate from quick clips of natives being blown-up with cannon balls, to men shooting at enemies and flying off of horses. Private Gent tries to stop the fight and is immediately arrested and removed from the battlefield. A noteworthy shot shows a bullet flying directly through a soldier's neck and the blood shooting out from both sides of the wound. The action becomes significantly worse on the second wave of attacks where the women, children, and elderly in the village are all unnatural victims who can do nothing to fight back and defend themselves. Viewers are forced to watch as a young Indian boy's face is shot straight through, a squaw gets her head chopped off by a saber, and teepees filled with children are set ablaze. Chivington sees a girl who has been maimed by the cannons and is missing a leg and decides to end the girl's suffering by shooting her down. Indian heads roll across the floor and survivors run around frantically. The soldiers also accost native women, strip them naked, and rape them. Others cheer the rapists on and torture the women by cutting off their breasts for souvenirs. The remaining Cheyenne non-combatants run to hide in a ravine, only to be shot to death from above.

Honus and Cresta are powerless to stop the soldiers and are horror-stricken by the sight of the all of the dead bodies covered in blood. Once all of the natives are gone, the soldiers cheer and dance around hoisting up flags, weapons, and severed Indian heads and limbs. They are so happy and excited about the devastation that they have caused that 
the director is clearly characterizing the Americans as the actual savages in his event. The scene ends with a congratulatory speech from the Colonel Chivington and jubilant music as the troop marches away from the desecrated campsite, both of which are oddly out of place. The final shot of countless Indian graves is accompanied by a silence that prompts audiences to honor the dead.

After the fighting is finished, a voiceover clarifies that the scene was meant to represent Colonel Chivington's attack on the Cheyenne at Sand Creek and gives the facts of the event. Viewers learn that the Colorado volunteer soldiers kill over five-hundred Indians, half of which are noncombatants, as well as rape and mutilate many. A quote from a high ranking, but uninvolved, Army official condemns the events of the day as one of the most foul and unjust crimes in the annals of American history. The soldier's statement works to separate the U.S. military as a whole from the guilty volunteers who participate in the attack, as though these men are criminals and not the employees of the government that sanctioned the assault. Soldier Blue is an important addition to the small sub-genre because it communicates a much clearer point about the horrors of American criminal violence than A Man Called Horse. The film's realistic fight scenes are meant to horrify viewers and draw an immense amount of sympathy for the Indians of the past and the Vietnamese of the present while simultaneously denouncing the Army as criminals.

Soldier Blue is most closely related to Arthur Penn's Little Big Man because both films have a compassionate view of Indians and portray a mutual disgust with everyday Americans. Penn's work is derived from Berger's novel. The film was the second biggest money maker of the 1970 movie season. One of the contributing factors to the novel's continued success is the fact that the film is very well known and helps to create interest 
and awareness for the author's work. The movie was filmed on location in Montana near the actual site of the Little Bighorn battlefield with a large cast of actors and extras for the time. The adaptation presents Jack Crabb as a senior citizen who recounts his life stories much like Berger's protagonist does in the novel, yet there are several differences between the two.

The film stars Dustin Hoffman at Jack Crabb, Faye Dunaway as Louise Pendrake, Chief Dan George as Old Lodge Skins, Cal Bellini as Younger Bear and Richard Mulligan as General Custer. Little Big Man is a forty-two year old film, yet it is a significant piece of Custeriana because it is still the most recent film to focus on General Custer. As Custer film expert, John Langellier, explains in his book-length study of the subject, Arthur Penn was the last director to focus on George Custer. After 1970, the General is highlighted as a part of television shows and series and only appears in cameo scenes as a background character in a handful of films. Penn's film fits with the conventions of Custeriana and the Vietnam Western because it portrays the U.S. in a very negative light and focuses on the plight of the natives.

Because Jack and his Indian friends are the decent and respectable characters, General Custer and his men are necessarily the villains. Penn's Custer is an extremely egotistical, unemotional, and merciless leader. He is seemingly unaffected when he first meets Jack and learns that economic misfortunes have led to family into bankruptcy and foreclosure. One of the next times Jack encounters the General, Custer is ready to have him hung as a renegade and cares little for the loss of human life. Finally, Custer appears as the most racist soldier of all when he describes the Indian women as breeding like rats and actually sanctions the killing of any females who resist the troop's assault. The film 
takes one final measure to negatively portray the Custer character at the Battle of Little Bighorn where the leader appears to completely lose his mind and dies as more of a maniacal joke than a military hero. The only positive thing that can be said for the character is that his idiotic actions make him a comical character that entertains audiences with his antics.

The film version of Little Big Man treats the three major conflicts in the novel that were previously discussed in chapter two. The majority of Penn's critics have written about the similarities and differences between the novel and the film version of the same story and either appreciated or denounced some of Penn's changes to the original. Because the topic has been discussed a number of times, the chief concern in the current study is the way that violence is represented in print and on screen by their respective creators. When Berger offers Jack Crabb's recollections of the events at the wagon train at the start of the story, he includes a whole chapter that details how the Cheyenne approach the settlers, enjoy whiskey to the point of inebriation, kill the white men, rape the white women, and return the next day. In contrast, the film version begins with the following statement: One hundred and eleven years ago, when I was ten years old, my family, in crossing the great plains, was wiped out by a band of wild Indians, everybody was kilt or drug off by them murderin' varmints. Penn's introduction is more veiled because it suggests that the entire family is killed or kidnapped by villains, but does not say why.

The panning screen shot shows that several wagons have been looted and set ablaze and the remaining possessions of the family are strewn all over the prairie. Two bloody bodies pierced with arrows lay in the background. The audible buzzing of flies 
suggests that they have already gone to work on the festering corpses. In this case, Jack and his sister are the only survivors. It is important to note that the camera arrives on the scene after the fight has concluded and the perpetrators are long gone. No violence is represented and only the desecrated site can attest to the struggle that must have taken place. The choice to forego a scene of graphic "frontier violence" allows Penn begin the film on a much lighter note and does not immediately shock viewers with examples of death and rape the way that he novel opens.

When compared with the other Vietnam Westerns, Little Big Man has the least severe opening of the three. The change from the novel is necessary if Penn wants to successfully characterize the Cheyenne as noble victims in the same way that other Vietnam Westerns do. In Berger's written version of the story, the Cheyenne kill the male settlers and adopt Crabb which adds to the difficulties in pinpointing the true native character or assigning blame and does not allow readers to separate them from their aggressive actions. In the visual representation of the hostilities, Crabb's voiceover denounces the Pawnee as the wagon train villains. Penn's substitution of one tribe for another creates very simplistic binary distinctions where the Pawnee are "bad" tribe and the Cheyenne are the "good" tribe. The characterization of the Pawnee as one of the most violent tribes seems to be a common theme in American Cinema that is still used years later when Kevin Costner includes the Pawnee as the barbaric antagonists in Dances with Wolves.

It is worth noting that that every film that has been reviewed for the current study, including Little Big Man, introduces racial violence with natives as the initial antagonists. In They Died with Their Boots On, Chief Crazy Horse and a group of warriors attack 
General Custer's wagon train seemingly without provocation. In Fort Apache, a band of braves kill and burn the soldiers running the telegraph wires. In A Man Called Horse a group of whites are hunting game birds and are peaceably camped along the river when they are killed, scalped, and burned by Sioux braves. In Soldier Blue a pay master's wagon train is attacked and all of the men are killed, viciously mutilated and burned. In Little Big Man Indians attack the family wagon without provocation. Though the details may vary, all of the films fail to include the background information on Indian and American relations that explains why the natives are ferociously attacking whites. Each of the brutal attacks reinforces the notion that the natives are to blame for the injustices that occur in western territory. The very idea that the artist has set out to create a compassionate portrait of Indians from American history, but starts the film with the most carnal representation of the characters as possible does not fit with the film's message. The Vietnam minded films later change their tone and re-assign the blame to the whites by the end of the movie, but it could be argued that the audiences' first impression of the Indians as sadistic killers may be too deep-seated to be overturned and ultimately subverts each director's best intentions.

The second conflict is the representation of the events at the Washita River. The scene occurs in the middle of the movie and is undoubtedly the most talked about portion of the film. Penn's version of the winter attack deliberately represents his opinion that the U.S. Army had slaughtered innocent victims at Washita just the same way that they had in the Vietnam War. The Mai Lai Massacre of 1968 was highly publicized for the brutal crimes that took place and audiences easily made the connection when Little Big Man was released. In the novel's version of the fight, Jack is classified as a renegade squaw 
man and struggles to move his family and Old Lodge Skins to safety. Half of his relations are killed and the other half go missing. Though Berger's story is tragic because some of the sisters die, it is not overly negative because the fates of both Sunshine and her child are never revealed and she may have survived.

In contrast, Arthur Penn's version manipulates the story to send a much different message about racial conflict. The scene runs for seven and a half minutes and is so difficult to watch that it seems to last much longer. In this representation, Jack is living with is wife Sunshine, their two children, and her three sisters. The camp is attacked and Crabb is unable to reach his family. Instead, he leads Old Lodge Skins to the other side of the river and watches as his wife and children are killed before his eyes. The violence is not as graphic as Soldier Blue because the injuries are not as realistic and there are minimal shots of the killings. The attack starts out with Indians running in all directions and for the ones who go down, it is unclear whether they trip or are shot. The main camera is situated inside of the Indian village so viewers experience the charge from the Indians' vantage point and are able to see the pandemonium as people run to escape certain death. The scene is so frantic that one would need to watch the film in slow motion to see exactly what is being presented. Crabb watches as the cavalry come thundering in between the teepees, use sabers and guns to kill Cheyenne men, women, children, and horses, and set the lodges on fire.

The first observable death occurs when a gunshot kills an Indian man and viewers see the blood spattered over his back as the lifeless body falls. As the assault goes on, more and more Cheyenne bodies are strewn on the snow covered ground. The next discernible view is of Indians fleeing burning teepees. Another camera is positioned 
across the river to catch a panoramic view of the entire campsite while the natives run across the screen towards safety. The wide shot shows just how severely the Indians are affected by the intrusion of the whites, but simultaneously works to obscure the violence because it is so far away. It might also be argued that the panoramic shot from the camera that is positioned well on the other side of the river and out of danger is done for symbolic reasons. The distanced camera could represent everyday Americans who knew or heard about the Vietnam War but were too far away to stop the bloodshed or affect an immediate change. As uninvolved spectators, Penn's viewers at the Washita River attack are far off and out of touch and it might be possible to say that Americans felt that very same way during the Vietnam War.

In what is undoubtedly the most serious part of the film, the director presents the fate of Sunshine and her three sisters. Viewers see two of the women bloodied and dying on the floor. Each time one of them moves, another gunshot is fired into their mangled bodies. The third sister flies out of their burning lodge naked under a blanket that is covered in flames. Though she tries to strip off the blazing cloth and make her escape, she is shot down by the troopers. Just then, Sunshine emerges from the shelter with a newborn in her arms and her older baby on her back. The young mother runs towards the safety of the river, but is closely pursued by a mounted trooper. Jack screams for her to run faster, but is too far away to help. A gunshot drops Sunshine to her knees, but she is able to recover and continues to run as the blood starts to seep out of the wound on her back. There is a second shot that kills the baby and a third that kills Sunshine. Her body falls facedown into the snow and Jack simultaneously falls to the ground. The scene ends with a wide shot of the desecrated Cheyenne camp, the frantic ponies that are about to be 
executed, three separate shots of dead Indians, and a final look at Sunshine's lifeless body. The close-ups of the dead natives contain a variety of age and sex. The shots may have been the director's way of showing that everyone in the camp was indiscriminately slaughtered by Americans at the Washita River and at Mai Lai.

The audio track is combined with the camera shots to create a severe environment that is meant to shock the viewing public. From the moment that the battle scene begins, the Irish tune "Garry Owen" plays on the soundtrack and the director focuses on the regimental band playing at a safe distance. The song drowns out a lot of the other noises in the camp, similar to Berger's description of the attack in the novel. The band's presence also draws attention to the absurdity of a government sanctioned execution set to jovial marching music and works to further characterize the American military as villains. The scene takes a turn for the worse as soon as Custer gives the order that all of the Indian ponies should be shot. Audiences watch the horses scream and thrash around as they die. The sights and sounds very realistic and viewers might shudder at the site of the ponies kicking around on the floor. The director chooses to drop the soundtrack completely at the most climactic point of the scene when Sunshine is killed. The last audible sounds are Jack's desperate cries for her to run for her life. As soon as the last bullet connects and she falls to the ground, the film track is muted and only a dead silence remains as the deceased mother and her babies appear on screen. The muteness draws attention to the death and might also be a symbolic moment of silence for the victims of similar crimes perpetuated by the American Army. The silence also calls attention to the fact that nothing can be said or done to make amends for what has occurred. 
The scene serves as the pinnacle of the film since Penn spends the most time and energy to make the audience disgusted with the government and the soldiers who kill such innocent people like Sunshine and her sisters. Film critic Pauline Kael takes an immediate dislike to the severity of Penn's Washita scene. As Kael argues, "Penn's greatest effort, is ironically, wasted, because by the time he gets to his full-scale climax he's lost us; it's a dull anticlimax, and we observe the slaughter without caring about it (214). Because Arthur Penn sets out to make a point about violence, most specifically at the Mai Lai Massacre of the Vietnam War, the Battle of Washita scene depicts violence in a very severe and disturbing, yet biased way. In the midst of all of the terror, Penn unrealistically presents Jack Crabb and all of the Cheyenne inhabitants as non-combatants, therefore as helpless victims. Contrary to historical records, George Custer's memoirs, and Berger's novel, there is never one instance in Penn's film where an Indian attempts to fight back against the invaders. The film also excludes any dead or wounded soldiers that were a part of the historical accounts, as well as the deaths of Major Elliot and his men. The slayings and mutilations are brutal acts from history that are necessarily hidden in Penn's account because he wants the natives to appear as immaculate beings that arouse compassion from viewers. Though the scene is not as coarse as the final scene of Soldier Blue, is does successfully send Penn's message about politics and violence in the 1970s.

The Battle of Little Bighorn is necessarily the final fight of Custer's life. In the novel, Crabb sides with the Americans and tells the entire story from the soldier's point of view, which guesses at what may have occurred at Custer's Last Stand and prompts readers to sympathize with the soldiers. In contrast, Penn's battle scene runs for little over five minutes. Though the Washita and the Little Bighorn scenes are almost equal in 
length, the Last Stand scene has much less of an impact. In this depiction, the Army begins an orderly ride towards the Indian camp on the opposite side of the river. The camera starts to the right of General Custer and is fixed in place as the cavalry goes trotting by. The next shot focuses on the Indian camp and it seems as though they can hear the soldiers coming.

When the troopers finally get their first view of the opponents, it appears that only a few male combatants are present. The cavalry chases a small group of natives over a hill. Custer can be heard yelling choice phrases such as, "we've caught them napping", "we have them on the run", and "take no prisoners", which show that he is merciless. At this point, warriors come barreling over a hill, diving across the river, and go speeding through prairie grass. In the meantime the soldiers continue to pursue the modest group of riders that they initially encounter. Each Indian carries a weapon as he rides and all that can be heard is the pounding of the horse's hooves and the Indians' war cries. Then the entire screen is suddenly clouded with gun smoke and prairie dust when the two sides almost collide at the top of the hill.

The camera is centered right where the two opposing groups will clash, but the shot cuts away before the two lines actually meet. The music that has been playing in the background since the start of the charge stops abruptly and from then on only the blasting guns and loud war cries are heard. The view is filled with countless natives riding by, but everyone moves so quickly that they never come into focus. There are two clear shots of General Custer's face when he sees the amount of Indians that are there to fight. He seems bewildered, but continues to shoot and rides into the fray. Then the director sporadically switches to a panoramic shot that gives an expansive view of the entire battle 
where the men appear the size of ants. The wide shot allows for the violence to go unseen and unnoticed.

Penn's version of Custer's Last Stand is virtually bloodless and centers on a lot of riding, yelling, and aimless gunfire. When the angle changes, men are presumably dying but viewers have only a split second to view each frame and do not see the killings. A group of soldiers are huddled in a small circle with their weapons and their horses and are barely visible through all of the dust and gun smoke. Indians wield tomahawks and skull crackers, but viewers do not see them connect with their victims. No killings are depicted. Just then, the General is violently thrown from his horse. Jack also falls off of his horse after taking an arrow in the chest; his wounds are the first sight of blood in the scene.

Nearby, the violence becomes more gruesome as an unknown soldier is hacked in the back with a tomahawk. The camera next focuses on Crabb who is incapacitated and losing blood. Viewers watch as dead soldiers begin to pile up. The corpses are strewn in different positions and are porcupined with arrows. Then the characters that have a name and a speaking part, such as Captain Benteen, begin to die. Custer continues his tirade and appears to be shocked and saddened when he realizes that they are all about to die. He then challenges the "savages" to come after him. The director uses this scene to leave a lasting memory of George Armstrong Custer as a laughable failure. The General does not do any fighting and is not helpful on the battlefield when he yells out ridiculous orders. At one point he screams, "Why aren't they charging?" and another man answers, "Because there's nowhere to charge to". The fact that the commander is not able to lead his men in a time of crisis only speaks to the failures of military policies that led the men 
there to lose their lives in vain. Custer is ultimately killed when Younger Bear shoots two Cheyenne arrows into his back.

The final shot widens on the main portion of the battlefield and shows the warriors milling around the dead soldier's bodies collecting souvenirs such as hats, guns, and cavalry flags. The most important aspect is that no scalping or mutilation is presented because Penn's tendency to ignore documented facts about the Indians' participation in the violence continues in the final battle of the film. There are also not any women and children involved, even though the novel and the historical records show that they are the ones who perform the majority of the mutilations. Any account of the Battle of Little Bighorn goes to great pains to describe the desecrated bodies and the challenges of identifying each man, but these details do not fit into Penn's story that treats the natives as innocent children who have been abused by their parents.

Though Penn's one-hundred thirty nine minute film could never hope to include all the intricacies of Berger's four-hundred forty page novel, the film is a memorable product of the Vietnam era because it offers a message about the atrocities that the U.S. has committed. Critical reviews often discount the film as just another Western or another movie about Indians, but unless a new wave of Custer films arrive in 2013 or later, Penn's work will serve as the most modern treatment of Custer's Last Stand and will set the tone for the way that American movie-goers remember George Armstrong Custer in the future. The notion that young Americans might watch the film and see a laughable failure in charge is disheartening and one can only hope that more even handed characterizations similar to Philbrick's treatment in The Last Stand will be produced. 


\section{CONCLUSION:}

The current study notes that the Battle of Little Bighorn is an event from American history that is very well-known and widely analyzed even in modern times. Although the story's evolution in the arts over the course of the last one-hundred thirty five years has been described in detail, it is worth questioning why this particular occurrence is still as popular as it is. Firstly, Custer's Last Stand was not the only "last stand" in history. The events with the Spartans at Thermopylae and at Davy Crockett at the Alamo are two of many other legendary "last stand" accounts. Secondly, Little Bighorn was not the first time that masses of whites were killed by Indians. As previously stated, there were years and years of conflict amongst the two groups and the natives overcame their opponents on a number of occasions. Specifically during Custer's lifetime the Fetterman Massacre resulted in the deaths of eighty Americans and was a precursor to the Battle of Little Bighorn where virtually the same events occurred with far worse outcome for the U.S. soldiers. As Philbrick theorizes in his study, perhaps the secret to Custer's undying fame is simply the centennial date of when the battle occurred. In contrast, Dippie argues that the image of Custer and the battle have been edited to fit the needs of the times and have signified several significant themes over the years.

In any case, the unknown events from the Battle of Little Bighorn stand out as one occurrence from military history that has been written and re-written, filmed and refilmed, for decades. It is important to note that the story of Custer's Last Stand is a moment in time when there were no whites to witness and communicate what actually took place. There were only witnesses from the Indian side who could offer an alternate 
set of evidence but accounts were often conflicted and affected by issues of translation and writer/editor biases in the 1870s. As the introduction to Soldier Blue states, mankind has recorded their history in blood. It seems fair to say that American history has been written by white for whites and that textbooks offer the history of the American victors written in her opponent's blood. During the 1960s when the world was experiencing massive changes in global relations, citizens began a new quest for knowledge and for understanding. The hunt led them back in time where they chose to question all of the previous accounts and re-evaluate who told the story, what he/she claimed occurred, and which perspectives were typically valued or devalued. The search uncovered a gaping hole in the histories of a number of Americans who were relegated to a lower standing, such as Native Americans and other races or ethnic groups, and even women and gays to a certain extent. The artists of the time made it their goal to return to history in an attempt to reconstruct what was missing. The native perspectives of the Indian Wars were a major part of that project and Berger was an interested student of the sub-genre of "Indian texts".

In reality, no American in 1876 or 2012 has any idea how history happened and that leaves a gap in the historical records that have typically valued the accounts that were seen by the white eye and recorded by the white hand. Just like the age old philosophical question, "If a tree falls in a forest and no one is around to hear it, does it make a sound?" A similar question applies in the case of Custer's Last Stand: If no Americans testified to the massacre did the event really occur? The sheer fact that writers have been trying to fill the void and create a "real" depiction of the historic event for the last one-hundred plus years testifies to America's need to know and to the impossibly of 
knowing. The only thing that remains to be seen is if novels and films about General George A. Custer and the Battle of Little Bighorn will continue on in the future or finally be laid to rest where they belong. 


\section{LIST OF REFERENCES}

A Man Called Horse. Dir. Elliot Silverstein. Paramount, 1970.

Ambrose, Stephen E. Crazy Horse and Custer: the Parallel Lives of Two American Warriors. New York: Anchor Books, 1996.

Arendt, Hannah. On Violence. New York: Harcourt, Brace, Jovanovich, 1970.

Berger, Thomas. Little Big Man. New York: Dial Trade Paperbacks, 2005.

Betts, Richard A. "Thomas Berger's Little Big Man: Contemporary Picaresque." Critique: Studies in Modern Fiction 23.2 (Winter 1981-82): 85-96.

Black Elk. Black Elk Speaks: Being the Life Story of a Holy Man of the Oglala Sioux. Comp. John G. Neihardt. Lincoln: University of Nebraska, 1988.

Bloom, Alexander, ed. Long Time Gone: Sixties American Then and Now. New York: Oxford UP, 2001.

Britt, Albert. Custer's Last Fight. Berkeley: University of California, 1944.

Calloway, Colin G. "Neither White Nor Red: White Renegades on the American Frontier" The Western Historical Quarterly 17.1 (1986): 43-66.

Chaiken, Michael, and Paul Cronin, eds. Arthur Penn Interviews. Jackson: University of Mississippi, 2008.

Custer, General George Armstrong. My Life on the Plains. Ed. Milo Milton Quaife. New York: Carole Group, 1990.

Dances with Wolves. Dir. Kevin Costner. TIG Productions, 1990.

Davis, David Brion. "Violence In American Literature." Annals of the American Academy of Political and Social Science. 364 (1966): 28-36.

Dippie, Brian W., and Kent L. Steckmesser. The Western Hero In History and Legend. N.p.: University of Oklahoma, 1997.

Ebert, Roger. "Little Big Man." Rogerebert.com. N.p., 1 Jan. 1970.

Fiedler, Leslie A. Love and Death in the American Novel. New York: Stein and Day, 1966.

Fort Apache. Dir. John Ford. RKO Pictures, 1948. 
Fraser, John. Violence in the Arts. [London]: Cambridge UP, 1974.

Green, Rayna. "The Tribe Called Wannabee: Playing Indian in America and Europe." Folklore 99.1 (1988): 130-55.

Hallowell, A. Irving. "American Indians, White and Black: The Phenomenon of Transculturalization." Current Anthropology 4.5 (1963): 519-31.

Hutton, Paul A. "From Little Bighorn to Little Big Man: The Changing Image of a Western Hero in Popular Culture." The Western Historical Quarterly 7.1 (1976): 19-45.

Kael, Pauline. Deeper into Movies. Boston: Little, Brown, 1973.

Kowalewski, Michael. Deadly Musings: Violence and Verbal Form in American Fiction. Princeton, NJ: Princeton UP, 1993.

Landon, Brooks. Thomas Berger. Boston: Twayne, 1989.

Langellier, John P. Custer: The Man, the Myth, the Movies. Mechanicsburg, PA:

Stackpole, 2000.

Little Big Man. Dir. Arthur Penn. Paramount Pictures, 1970.

Pearce, Roy Harvey., Savagism and Civilization: a Study of the Indian and the American Mind. Berkeley: University of California, 1988.

Philbrick, Nathaniel. The Last Stand: Custer, Sitting Bull, and the Battle of the Little Bighorn. New York: Viking, 2010.

Richter, Conrad. The Light in the Forest: A Novel. New York: Vintage, 1953.

Rogers, Mike. "Review of The Last Stand: Custer, Sitting Bull, and the Battle of the Little Bighorn." Library Journal (2010): 19.

Scarry, Elaine. The Body in Pain: The Making and Unmaking of the World. New York: Oxford UP, 1985.

Sinowitz, Michael Leigh. "The Western as Postmodern Satiric History: Thomas Berger's Little Big Man." Clio 28.2 (Winter 1999): 129-48.

Soldier Blue. Dir. Ralph Nelson. Lionsgate, 1970.

They Died With Their Boots On. Dir. Raoul Walsh. Warner Bros. Pictures, Inc., 1941. 
Turner, Frederick. "The Second of 'Little Big Man"' The Nation (1977): 149-51.

Turner, John W. "Little Big Man, the Novel and the Film: A Study of Narrative Structure." Literature/Film Quarterly Spring 5.2 (1977): 154-163. Web. 1 Jan. 2011. 